\title{
Oxygen fluxes beneath Arctic land-fast ice and pack ice: towards estimates of ice productivity
}

\author{
Karl M. Attard ${ }^{1,2,3}$. Dorte H. Søgaard ${ }^{3}$. Judith Piontek ${ }^{4}$ Benjamin A. Lange B $^{5,6}$. Christian Katlein ${ }^{5}$ \\ Heidi L. Sørensen ${ }^{1}$ - Daniel F. McGinnis ${ }^{7,8}$ • Lorenzo Rovelli ${ }^{1}$. Søren Rysgaard ${ }^{3,9,10}$ • Frank Wenzhöfer ${ }^{5,11}$. \\ Ronnie N. Glud ${ }^{1,12}$
}

Received: 10 January 2018 / Revised: 25 April 2018 / Accepted: 4 June 2018 / Published online: 12 June 2018

(c) The Author(s) 2018

\begin{abstract}
Sea-ice ecosystems are among the most extensive of Earth's habitats; yet its autotrophic and heterotrophic activities remain poorly constrained. We employed the in situ aquatic eddy-covariance (AEC) $\mathrm{O}_{2}$ flux method and laboratory incubation techniques $\left(\mathrm{H}^{14} \mathrm{CO}_{3}{ }^{-},\left[{ }^{3} \mathrm{H}\right]\right.$ thymidine and $\left[{ }^{3} \mathrm{H}\right]$ leucine) to assess productivity in Arctic sea-ice using different methods, in conditions ranging from land-fast ice during winter, to pack ice within the central Arctic Ocean during summer. Laboratory tracer measurements resolved rates of bacterial $\mathrm{C}$ demand of $0.003-0.166 \mathrm{mmol} \mathrm{C} \mathrm{m}^{-2}$ day $^{-1}$ and primary productivity rates of $0.008-0.125 \mathrm{mmol} \mathrm{C} \mathrm{m}^{-2}$ day $^{-1}$ for the different ice floes. Pack ice in the central Arctic Ocean was overall net autotrophic $\left(0.002-0.063 \mathrm{mmol} \mathrm{C} \mathrm{m}^{-2} \mathrm{day}^{-1}\right)$, whereas winter land-fast ice was net heterotrophic $\left(-0.155 \mathrm{mmol} \mathrm{C} \mathrm{m}^{-2}\right.$ $\mathrm{day}^{-1}$ ). AEC measurements resolved an uptake of $\mathrm{O}_{2}$ by the bottom-ice environment, from - $2 \mathrm{mmol} \mathrm{O}_{2} \mathrm{~m}^{-2} \mathrm{day}^{-1}$ under winter land-fast ice to - $6 \mathrm{mmol} \mathrm{O}_{2} \mathrm{~m}^{-2}$ day $^{-1}$ under summer pack ice. Flux of $\mathrm{O}_{2}$-deplete meltwater and changes in water flow velocity masked potential biological-mediated activity. AEC estimates of primary productivity were only possible at one study location. Here, productivity rates of $1.3 \pm 0.9 \mathrm{mmol} \mathrm{O}_{2} \mathrm{~m}^{-2} \mathrm{day}^{-1}$, much larger than concurrent laboratory tracer estimates $\left(0.03 \mathrm{mmol} \mathrm{C} \mathrm{m}^{-2} \mathrm{day}^{-1}\right)$, indicate that ice algal production and its importance within the marine Arctic could be underestimated using traditional approaches. Given careful flux interpretation and with further development, the AEC technique represents a promising new tool for assessing oxygen dynamics and sea-ice productivity in ice-covered regions.
\end{abstract}

Keywords Sea-ice $\cdot$ Primary production $\cdot$ Bacterial production $\cdot$ Carbon cycling $\cdot$ Eddy-covariance

Karl M. Attard

karl.attard@biology.sdu.dk

1 Department of Biology, University of Southern Denmark, 5230 Odense, Denmark

2 Tvärminne Zoological Station, University of Helsinki, J.A. Palménin tie 260, 10900 Hanko, Finland

3 Greenland Climate Research Centre, Greenland Institute of Natural Resources, 3900 Nuuk, Greenland

4 GEOMAR, Helmholtz Centre for Ocean Research Kiel, Kiel, Germany

5 Alfred Wegener Institute, Helmholtz Centre for Polar and Marine Research, Bremerhaven, Germany

6 University of Hamburg, Centre for Natural History (CeNak), Zoological Museum, Martin-Luther-King Platz 3, 20146 Hamburg, Germany

7 Aquatic Physics Group, Department F.-A. Forel for Environmental and Aquatic Sciences (DEFSE), Section of Earth and Environmental Sciences, Faculty of Sciences, University of Geneva, Uni Carl Vogt, 66 Boulevard Carl-Vogt, 1211 Geneva, Switzerland

8 Leibniz-Institute of Freshwater Ecology and Inland Fisheries (IGB), Mueggelseedamm 310, 12587 Berlin, Germany

9 Clayton H. Riddell Faculty of Environment Earth and Resources, University of Manitoba, Winnipeg, MB R3T 2N2, Canada

10 Arctic Research Centre, Department of Bioscience, Aarhus University, 8000 Aarhus, Denmark

11 HFG-MPG, Joint Research Group for Deep Sea Ecology and Technology, Max Planck Institute for Marine Microbiology, Bremen, Germany

12 Department of Ocean and Environmental Sciences, Tokyo University of Marine Science and Technology, Tokyo 108-8477, Japan 


\section{Introduction}

\section{Sea-ice ecosystems}

Sea-ice annually covers $\sim 25$ million $\mathrm{km}^{2}$ of Earth's surface (Parkinson and DiGirolamo 2016). In the central Arctic Ocean, sea-ice extent ranges from $\sim 15$ million $\mathrm{km}^{2}$ in March to $<4$ million $\mathrm{km}^{2}$ in September, and additionally covers numerous fjords, sounds, and embayments at lower latitudes (Arrigo 2014; NSIDC 2017). Sea-ice provides a complex and rigid floating structure in an otherwise open ocean, and supports diverse lifeforms that range from microorganisms living within the ice matrix to fish, birds, and mammals seeking sanctuary on or beneath the ice (Thomas 2017). The bottom-ice layer typically is the most biologically-productive sea-ice habitat. Microscopic algae that accumulate within this region due to favorable growth conditions constitute a primary food source for grazers located within the immediate vicinity of the ice pack (Kohlbach et al. 2016). In aggregated forms, algae can sink rapidly to depths of several kilometers and sustain opportunistic deep-sea benthic communities (Boetius et al. 2013). Living in close association with the ice algae are heterotrophic microbes that play a significant role in the sea-ice microbial ecosystem. Through diverse metabolic functions and interactions, communities of protists and bacteria effect key biogeochemical transformations of carbon and nutrients in Arctic surface waters (Bowman 2015).

Organisms inhabiting the sea-ice are at the mercy of a highly unpredictable ecosystem where thermodynamics, divergence, and deformation processes continuously alter habitat characteristics (Thomas 2017). During ice formation, dissolved constituents of seawater such as the salts and gases are expelled from the ice. With sustained cooling from the atmosphere, ice grows in thickness. The accumulated brines percolate through the ice matrix and under the action of gravity are forced downward, forming vertical interlinked channels through the ice and draining to the underlying waters. Sea-ice is therefore largely depleted of dissolved salts and gases, but the brine channels form a mosaic of microsites within the ice pack which typically are at or close to saturation with respect to dissolved gases (Glud et al. 2002; Zhou et al. 2014; Galley et al. 2015). Colder ice temperatures favor low brine volume, high brine salinity, and low permeability of the ice matrix (Cox and Weeks 1983). During the ice thaw, or under thick snow cover, ice porosity increases, and meltwater dilutes the existing brines and exchanges fluid with underlying waters (Hunke et al. 2011). Ice temperature, brine volume, and light availability alter the sea-ice $\mathrm{O}_{2}$ pool through stimulating microbial respiration and primary production.
In warmer months and under light-limiting conditions (due to e.g., snow cover), the sea-ice $\mathrm{O}_{2}$ pool may be further depleted through enhanced microbial respiration, potentially permitting anaerobic respiration pathways such as denitrification and anammox that influence nutrient availability for primary producers (Rysgaard and Glud 2004; Rysgaard et al. 2008). Sympagic primary productivity rates and the distribution of photosynthetic organisms are further influenced by surface ice conditions such as snow thickness, melt-pond cover, and ice topography (Katlein et al. 2014, 2015).

\section{Constraining autotrophic and heterotrophic activity in sea-ice}

While many of the mechanisms described above are wellknown, measurements of autotrophic and heterotrophic activity rates, two key processes occurring within sea-ice, are relatively scarce within the literature. This is especially the case for measurements performed under in situ conditions whereby environmental conditions within the ice pack remain unaltered. Previous studies have documented that sea-ice productivity is dynamic and is driven by complex interactions between variables such as current strength and sunlight availability (McMinn et al. 2000). Sea-ice presents a challenge for productivity studies in that the ice pack is a solid, often uneven surface with a patchy distribution of biotic communities (Rysgaard et al. 2001; Glud et al. 2014; Katlein et al. 2014). Laboratory incubation techniques $\left(\mathrm{H}^{14} \mathrm{CO}_{3}{ }^{-}\right.$and $\left[{ }^{3} \mathrm{H}\right]$ thymidine $)$ are the standard and widely accepted approach to assess rates of biological processes in sea-ice. However, incubation techniques are highly invasive and invoke considerable assumptions with scaling, core collection, sectioning, melting, and incubation of the meltwater in the laboratory (Miller et al. 2015). The heterogeneous nature of sea-ice makes tracers homogenization a challenge. Methods utilizing $\mathrm{O}_{2}$ in combination with inert gases (e.g., $\mathrm{O}_{2}$ :Ar) (Zhou et al. 2014) represent a promising new tool for investigating sea-ice productivity, but similarly require extraction of ice cores from the environment for laboratory analysis. In situ techniques such as pulse amplitude modulation (PAM) fluorometry and oxygen microprofiling at the ice-water interface are less invasive, but integrate over micro-scale regions of the under-ice habitat, and replication is difficult (McMinn et al. 2000; Kuhl et al. 2001; Rysgaard et al. 2001; Glud et al. 2002). It is therefore necessary to consider other non-invasive, complementary methods that are capable of integrating heterogeneous under-ice communities, such as sparsely-distributed ice algal encrustations and aggregates (Miller et al. 2015).

In recent years, sea-ice productivity has been quantified from direct, non-invasive biogeochemical $\mathrm{O}_{2}$ flux measurements at the ice-water interface using an aquatic 
eddy-covariance (AEC) approach (Long et al. 2012), a method originally designed for benthic applications (Berg et al. 2003). The AEC method infers areal-averaged fluxes of $\mathrm{O}_{2}$ at the ice-water interface, typically in mmol $\mathrm{O}_{2} \mathrm{~m}^{-2}$ day $^{-1}$, by quantifying the turbulent transport of $\mathrm{O}_{2}$ from within the under-ice boundary layer at some distance $(\sim 0.5 \mathrm{~m})$ beneath the ice. Advantages of this method include its non-invasive nature, as well as its ability to integrate over patchy and heterogeneous biotic communities and surfaces (Rheuban and Berg 2013). While the AEC method clearly holds great potential for autotrophic and heterotrophic activity studies in sea-ice, the $\mathrm{O}_{2}$ fluxes at the ice-water interface, from which the productivity measurements are derived, are influenced not only by biotic processes of photosynthetic production and respiration, but also by thermodynamic processes of ice freezing and melting (Glud et al. 2002, 2014; Long et al. 2012). To our knowledge there exist just three applications of the AEC $\mathrm{O}_{2}$ flux method to sea-ice: flux measurements beneath land-fast ice in a sub-Arctic fjord in Greenland (Long et al. 2012), pack ice in the Fram Strait (Glud et al. 2014), and a sea-ice pool study by Else et al. (2015).
In this study, we investigate sea-ice productivity using AEC and traditional laboratory incubation approaches in different high-Arctic settings, representing a wide range of ice types and environmental conditions. The data are used to evaluate sea-ice productivity and its drivers as measured using the AEC technique, and how these values compare to laboratory incubation approaches.

\section{Materials and methods}

\section{Study locations}

This study incorporates data collected during two separate research expeditions to the high Arctic in 2012. The first expedition took place in March at the Daneborg field station $\left(74^{\circ} 18.57^{\prime} \mathrm{N}, 20^{\circ} 18.27^{\prime} \mathrm{W}\right)$ located in Young Sound, North-east Greenland (Fig. 1) (Rysgaard and Glud 2007). Sea-ice at this location is typical of fjord ice in the Arctic, often covered by large amounts of snow. Sampling here was performed at a single location on land-fast ice (ICE1 , hereafter referred to as 'DNB') located $\sim 2 \mathrm{~km}$ away
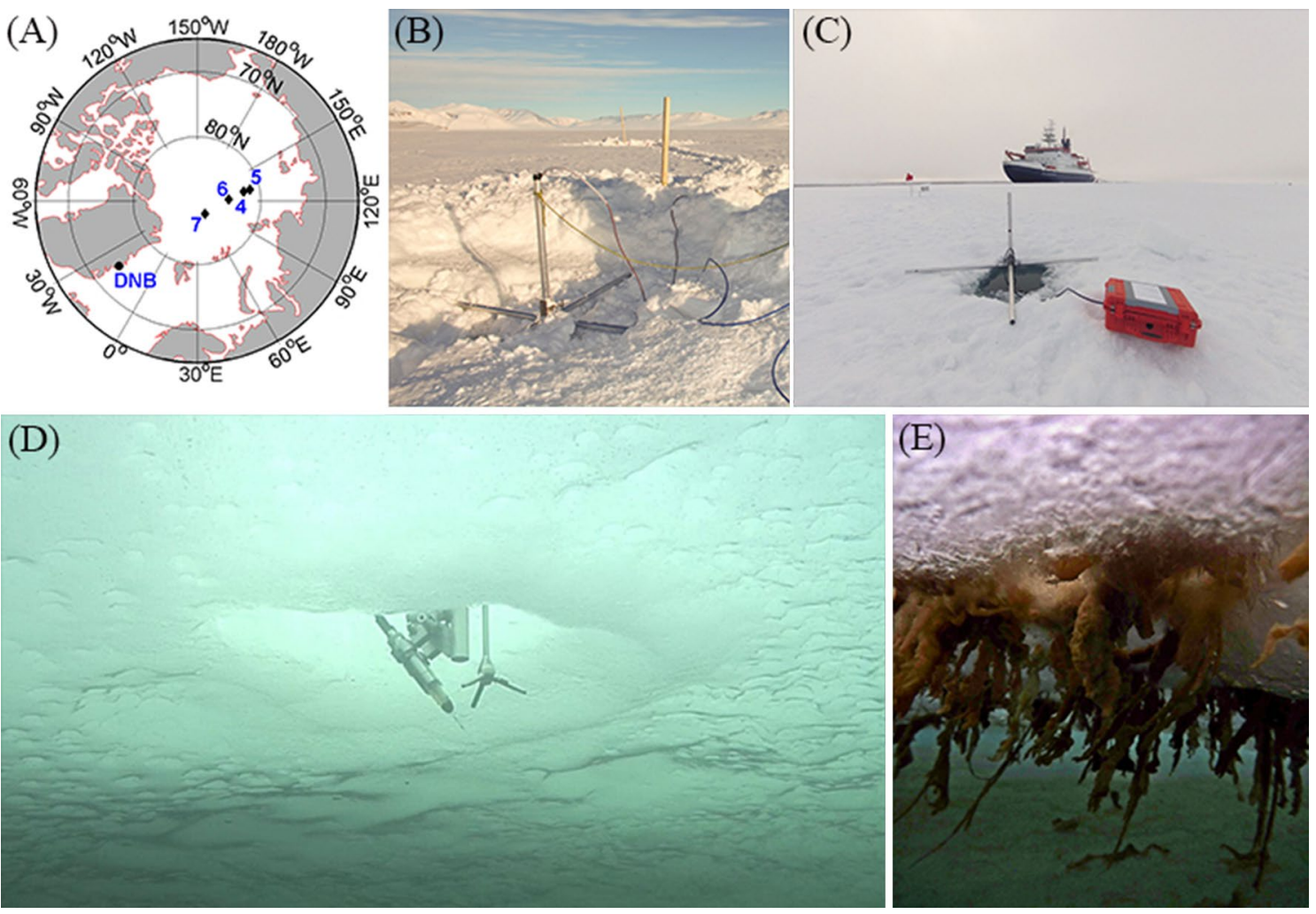

Fig. 1 Geographical location of the five measurement sites in Northeast Greenland (station DNB) and the central Arctic Ocean (stations Ice 4 to Ice 7; a), b a top-side view of an AEC instrument deployed at station DNB in Greenland, $\mathbf{c}$ a top-side view of an AEC instrument deployed in the central Arctic Ocean, $\mathbf{d}$ an AEC instrument viewed from below the ice using the ROV, and e filamentous strands formed by the centric diatom Melosira arctica attached to the underside of the ice in the central Arctic Ocean Photo by M. Fernández-Méndez taken nearby station Ice 7 
from the Daneborg field station (Rysgaard et al. 2013). A second expedition took place later that year to the central Arctic Ocean (RV Polarstern IceArc Expedition (ARK273), 2 August to 8 October; Fig. 1) (Boetius 2013). Successful measurements during this second campaign were performed on pack ice at four separate ice stations, located between 82 and $87^{\circ} \mathrm{N}$, and cover a range of environmental conditions, ranging from first-year sea-ice (FYI) with high melt-pond cover at the ice edge, to thicker multi-year ice (MYI) nearby the geographic North Pole (Fig. 1).

\section{Environmental conditions above the ice}

Weather stations located at the Daneborg field station and on the research vessel measured air temperature $\left({ }^{\circ} \mathrm{C}\right)$, wind velocity $\left(\mathrm{m} \mathrm{s}^{-1}\right)$ and direction, and incident solar radiation $\left(\mathrm{W} \mathrm{m}^{-2}\right.$ ) during both sampling campaigns at 10 min intervals. Incident solar radiation was converted to incoming photosynthetically active radiation (PAR, in $\mu$ mol photons $\mathrm{m}^{-2} \mathrm{~s}^{-1}$ ) following calibration on-site to a Li-Cor Quantum 2-pi sensor $\left(R^{2}>0.95\right.$; Li-Cor Biosciences).

\section{Ice temperature and salinity}

Measurements of ice temperature and salinity were performed on ice core samples, extracted using a Mark II Coring System ( $9 \mathrm{~cm}$ inner diameter, Kovacs Enterprises, Roseburg, Oregon, USA). Ice temperature was measured at $5-10 \mathrm{~cm}$ intervals using a calibrated digital penetration thermometer (Testo Limited, Hampshire, United Kingdom). Ice salinity was calculated from conductivity measurements performed on melted sections of the ice cores. The cores were cut into $10 \mathrm{~cm}$ sections using a stainlesssteel saw, and the individual sections were kept thawing in the dark and at a temperature of $3 \pm 1{ }^{\circ} \mathrm{C}$. Approximately $48 \mathrm{~h}$ later, once the samples had thawed completely, conductivity measurements were performed using conductivity sensors (Thermo Orion-Star with an Orion 013610MD conductivity cell, ThermoFisher Scientific, Massachusettes, USA; WTW 3300i, Wissenschaftlich-Technische Werkstätten $\mathrm{GmbH}$, Weilheim, Germany). Ice salinity was subsequently calculated from conductivity according to Grasshoff et al. (2007).

Sea-ice brine volume for intact ice samples was calculated from measured ice salinity, bulk density, and temperature according to Leppäranta and Manninen (1988) for temperatures $>-2{ }^{\circ} \mathrm{C}$, and according to Cox and Weeks (1983) for temperatures $<-2{ }^{\circ} \mathrm{C}$. Ice porosity $(\phi)$, also known as 'void fraction', was calculated from ice density $(\sigma)$ as $\phi=1-\sigma_{\text {bulk }} / \sigma_{\text {ice }}$, where a value of $917 \mathrm{~kg} \mathrm{~m}^{-3}$ was used for pure ice (Yen et al. 1991).

\section{Sea-ice primary productivity and bacterial C demand measurements}

Depth-integrated measurements of potential sea-ice primary productivity and bacterial $\mathrm{C}$ demand were performed following standard procedures as described by Søgaard et al. (2010). The advantages and disadvantages of these methods are well-known and have been given careful consideration within the literature (Miller et al. 2015; Campbell et al. 2017). Potential sea-ice primary productivity $\left(\mathrm{PP}_{\mathrm{i}}\right)$ was quantified by performing $\mathrm{H}^{14} \mathrm{CO}_{3}{ }^{-}$incubations on melted ice sections under different irradiance levels $(260,140,43$, $0 \mu \mathrm{mol}$ photons $\mathrm{m}^{-2} \mathrm{~s}^{-1}$ ). Individual incubations lasted $5 \mathrm{~h}$ and were maintained at a temperature of $3 \pm 1{ }^{\circ} \mathrm{C}$. Illumination was provided from a $150 \mathrm{~W}$ fiber optic tungsten-halogen bulb that emits light with a spectral distribution similar to that of natural sunlight. Primary productivity rates (in $\mu \mathrm{g} \mathrm{C} \mathrm{kg}{ }^{-1}$ ice $\mathrm{h}^{-1}$ ) for each sea-ice section were dark-corrected, plotted against the irradiance levels, and fitted with the photosynthesis-irradiance (P-E) function described by Platt et al. (1980) using a least-squares approach. Derived P-E relationships for the different ice depths were scaled to hourly measurements of above-ice incident irradiance, accounting for light attenuation due to overlying snow and ice as described by Søgaard et al. (2010). Depth-integrated rates of daily $\mathrm{PP}_{\mathrm{i}}$ (in mmol C m${ }^{-2}$ ice day ${ }^{-1}$ ) were calculated as the sum of the daily $\mathrm{PP}_{\mathrm{i}}$ at the different ice depths.

Sea-ice bacterial $\mathrm{C}$ demand rates $\left(\mathrm{BP}_{\mathrm{i}}\right)$ were similarly determined using incubation techniques for different sections of melted sea-ice. In Greenland, measurements were performed directly on melted sea-ice samples, whereas in the central Arctic, ice core sections were melted in a known volume of artificial seawater. In all cases, a slow melting process was applied (Mikkelsen and Witkowski 2010). $\mathrm{BP}_{\mathrm{i}}$ was determined from incorporation of either tritiumlabeled thymidine $\left(\left[{ }^{3} \mathrm{H}\right]\right.$ thymidine, Greenland campaign) or $\left[{ }^{3} \mathrm{H}\right]$ leucine (central Arctic Ocean). In Greenland, triplicate samples of $10 \mathrm{~mL}$ meltwater were extracted from each melted ice section, and were incubated for $6 \mathrm{~h}$ in darkness at $3 \pm 1{ }^{\circ} \mathrm{C}$ with $10 \mathrm{nM}$ of labeled $\left[{ }^{3} \mathrm{H}\right]$ thymidine (specific activity $10.1 \mathrm{Ci} \mathrm{mmol}^{-1}$, New England Nuclear), along with trichloroacetic acid (TCA) - killed controls to measure potential abiotic adsorption. At the end of the incubation period, $1 \mathrm{~mL}$ of $50 \%$ cold TCA was added to all the samples for fixation. The samples were filtered and counted using a liquid scintillation analyzer (TricCarb 2800, PerkinElmer). $\mathrm{BP}_{\mathrm{i}}$ measurements for the Arctic Ocean campaign were quantified from the uptake of $\left[{ }^{3} \mathrm{H}\right]$ leucine (specific activity $107.7 \mathrm{Ci} \mathrm{mmol}^{-1}$, Perkin Elmer). Subsamples of $20 \mathrm{~mL}$ were incubated with $\left[{ }^{3} \mathrm{H}\right]$ leucine at a final concentration of $20 \mathrm{nmol} \mathrm{L}^{-1}$ for $13-17 \mathrm{~h}$. Incubation was terminated by adding TCA at a final concentration of 5\%. Cells were then collected by filtration onto $0.2 \mu \mathrm{m}$-polycarbonate filters. Each 
filter was rinsed three times with $1 \mathrm{~mL}$ of a $5 \%$ TCA solution. Filters were dried and the incorporation of $\left[{ }^{3} \mathrm{H}\right]$ leucine into the TCA-insoluble fraction was measured by liquid scintillation counting, performed on-board the research vessel after addition of scintillation cocktail (Ultima Gold $\mathrm{AB}$, Perkin Elmer). Results were corrected for dilution with artificial seawater and for abiotic absorption estimated from TCA-killed controls. For both $\left[{ }^{3} \mathrm{H}\right]$ thymidine and $\left[{ }^{3} \mathrm{H}\right]$ leucine treatments, bacterial $\mathrm{C}$ production was calculated using the conversion factors presented in Smith and Clement (1990). Carbon production rates were divided by growth efficiency (0.5) (Rivkin and Legendre 2001) to compute bacterial $\mathrm{C}$ demand (in $\mu \mathrm{g} \mathrm{C} \mathrm{kg}{ }^{-1}$ ice $\mathrm{h}^{-1}$ ), and the values for the individual ice layers were subsequently summed to derive depth-integrated rates (in mmol $\mathrm{C} \mathrm{m}^{-2} \mathrm{day}^{-1}$ ). For comparison of $\mathrm{PP}_{\mathrm{i}}$ and $\mathrm{BP}_{\mathrm{i}}$ with other rate measurements, we assume a $\mathrm{C}: \mathrm{O}_{2}$ of 1.0 .

\section{Environmental conditions beneath the ice}

A conductivity-temperature-depth (CTD) sonde (SBE 19 plus V2, Seabird) was deployed at $0.5-1.0 \mathrm{~m}$ depth beneath the ice to monitor the under-ice environmental conditions. The CTD logged water temperature, salinity, depth, PAR (QCP-2000, Biospherical Instruments), and $\mathrm{O}_{2}$ concentration in the water by means of a calibrated optode (4340, Aanderaa) at $30 \mathrm{~s}$ intervals.

During the central Arctic Ocean expedition, light transmittance through sea-ice was measured using a RAMSESACC hyperspectral radiometer (TriOS Datentechnik, Rastede, Germany) carried on-board a V8-Sii (Ocean Modules, Åtvidaberg, Sweden) remotely operated vehicle (ROV). The vehicle, operated directly from the ice through a manually cut access hole, was piloted beneath the ice along horizontal transects to resolve the spatial variability in light transmittance due to e.g., melt ponds and ridges (Nicolaus and Katlein 2013). Successful ROV dives were performed at all ice stations except for Ice 4, where the ROV could not be operated due to an electronic failure. Measurements with a distance of more than $2 \mathrm{~m}$ to the ice were discarded during processing. Details about the deployment method and data processing can be found in the report by Katlein et al. (2012).

\section{Microgradients of $\mathrm{O}_{2}$ at the ice-water interface}

Vertical microprofiles of $\mathrm{O}_{2}$ at the ice-water interface were obtained in situ using an underwater microprofiling unit (Boetius and Wenzhoefer 2009), that was mounted onto an ice profiler system with an articulated arm. The ice profiler, similar to the system of McMinn et al. (2000), consisted of a horizontal arm carrying an elevator system and an underwater electronic cylinder housing. The sensor module consisted of two Clark-type $\mathrm{O}_{2}$ microelectrodes, one resistivity sensor, and one temperature sensor for high-resolution measurements, together with an oxygen optode (Aanderaa 4330) and an underwater PAR sensor (Li-Cor UWQ8312). The instrument was deployed through a $50 \times 50 \mathrm{~cm}$ ice hole. The articulated arm positioned the sensors $2 \mathrm{~m}$ away from the hole, to minimize light interference. The raw $\mathrm{O}_{2}$ microsensor output was calibrated to the dissolved $\mathrm{O}_{2}$ concentration in $\mu \mathrm{mol} \mathrm{O}_{2} \mathrm{~L}^{-1}$ in water and ice using a two-point calibration. The first point was obtained from the in situ $\mathrm{O}_{2}$ concentration in the water as measured by the optode, and the second point was obtained in the laboratory as the zero sensor reading. A thin metal rod attached to the electronic cylinder protruded $5 \mathrm{~cm}$ longer than the sensors, and was used as a reference for initial sensor array positioning directly below the sea-ice interface. The microsensors were then programmed to sample and record data while moving at $100 \mu \mathrm{m}$ vertical steps toward the ice. We limit our interpretation of the microprofiles to the ice-water interface (i.e., water-side measurements) only, since the microsensor signal output may be compromised when in contact with solid ice crystals (Glud et al. 2002).

\section{Eddy-covariance $\mathrm{O}_{2}$ fluxes}

Fluxes of $\mathrm{O}_{2}$ between sea-ice and the underlying water were quantified using our standard AEC system that is similar to the original design used by Berg and Huettel (2008) for measuring benthic fluxes of $\mathrm{O}_{2}$. This instrument consists of a $6 \mathrm{MHz}$ acoustic Doppler velocimeter (ADV; Nortek, Norway) and two Clark-type $\mathrm{O}_{2}$ microsensors that relay an amplified signal to the velocimeter via submersible amplifiers (Revsbech 1989; McGinnis et al. 2011). The microsensors were individually tested for their quality prior to deployment, and had a $90 \%$ response time of $\leq 0.3$ s and a stirring sensitivity of $\leq 1 \%$ (Gundersen et al. 1998). Sensor stirring sensitivity effects on the $\mathrm{O}_{2}$ fluxes were estimated using the formulations provided by Holtappels et al. (2015) to be a minor bias in the data $(<7 \%)$. The $\mathrm{O}_{2}$ sensors were affixed to the stem of the ADV using a polyoxymethylene mounting and the sensors were positioned at an angle of $60^{\circ}$ relative to the velocimeter, with the $\sim 20 \mu \mathrm{m}$ microsensor tips located $0.5 \mathrm{~cm}$ away from the instrument's $2.65 \mathrm{~cm}^{3}$ cylindrical-shaped measurement volume (McGinnis et al. 2011). The AEC instrumentation was deployed vertically through a hole in the ice, attached to a sturdy $2 \mathrm{~m}$-long aluminum pipe section with the measurement volume located at a depth of $\sim 0.5 \mathrm{~m}$ below the ice (Fig. 1) (Long et al. 2012). Online readings were used to align the instrument coordinates within the main flow direction. Flow velocity and $\mathrm{O}_{2}$ microsensor output were logged in continuous sampling mode at $64 \mathrm{~Hz}$, with measurements periodically being interrupted for data download or sensor replacement. 
Processing of the raw AEC data followed established protocols for bin-averaging the $64 \mathrm{~Hz}$ data to $8 \mathrm{~Hz}$, despiking, coordinate rotation, and quality checking individual flux intervals for anomalous data such as jumps in $\mathrm{O}_{2}$ concentration (Lorrai et al. 2010; Long et al. 2012; Berg et al. 2013; Attard et al. 2015; Else et al. 2015). Sensor calibration, flux extraction, and time-shifting of the $\mathrm{O}_{2}$ data for maximum numerical flux were performed using the Sulfide Oxygen Heat Flux Eddy Analysis (SOHFEA) software (www.dfmcg innis.com/SOHFEA) (McGinnis et al. 2014). The raw $\mathrm{O}_{2}$ microsensor signal was calibrated using linear regression against in situ $\mathrm{O}_{2}$ concentrations obtained from an $\mathrm{O}_{2}$ optode that was located on the nearby ( $\sim 20 \mathrm{~m}$ distant $)$ CTD sonde. Impacts of averaging timescales and sensor response on the $\mathrm{O}_{2}$ flux were investigated by expressing the vertical flux $\overline{w^{\prime} O_{2}^{\prime}}$ as the integrated value of the cospectrum of $w^{\prime} O_{2}^{\prime}$ in the frequency $(f)$ domain (termed 'cumulative cospectra') (Berg et al. 2003; Lorrai et al. 2010), as

$\overline{w^{\prime} O_{2}^{\prime}}=\int_{0}^{\infty} C o_{w^{\prime} O_{2}^{\prime}}(f) \mathrm{d} f$.

The cumulative cospectra were used to evaluate the frequency of the flux-contributing turbulent eddies, the optimal averaging time scales to use for scalar flux extraction, as well as any flux loss from spectral attenuation due to sensor response time and separation distances (Lorke et al. 2013; Donis et al. 2015). Following this analysis, fluxes of $\mathrm{O}_{2}$ in $\mathrm{mmol} \mathrm{O}_{2} \mathrm{~m}^{-2}$ day $^{-1}$ were extracted using linearly detrended 15 min ensemble average intervals that were subsequently bin-averaged to $1 \mathrm{~h}$ intervals. Positive $\mathrm{O}_{2}$ fluxes indicate a release of $\mathrm{O}_{2}$ by the bottom-ice environment and negative fluxes indicate $\mathrm{O}_{2}$ uptake.

\section{Constraining the $\mathrm{O}_{2}$ flux due to basal ice melt}

The $\mathrm{O}_{2}$ flux due to bottom-ice formation or melt was estimated from heat flux measurements performed at the ice-water interface as described by Long et al. (2012). At the DNB site, heat flux measurements were performed by direct covariance, using a fast-response temperature sensor (FP07, ISW Wassermesstechnik, Germany; accuracy $\pm 0.02^{\circ} \mathrm{C}$, resolution $0.002{ }^{\circ} \mathrm{C}$, response time $10 \mathrm{~ms}$ ) that was interfaced with the ADV. Data processing followed the same procedure described above for extracting the $\mathrm{O}_{2}$ fluxes from the raw data streams, and the fluxes of heat $\left(H_{\mathrm{f}}\right.$, in $\left.\mathrm{W} \mathrm{m}^{-2}\right)$ were calculated according to the equation

$H_{\mathrm{f}}=\overline{w^{\prime} T^{\prime} \rho_{\mathrm{sw}} C_{\mathrm{p}}}$,

where $T$ is water temperature, $\rho_{\mathrm{sw}}$ and $C_{\mathrm{p}}$ the density and specific heat capacity of seawater, respectively. Because direct covariance fluxes of heat were only available during the first campaign, the under-ice ocean heat flux for the second research campaign was estimated from bulk measurements of water temperature elevation above freezing $\left(\delta_{\mathrm{T}}\right)$ and friction velocity $\left(u_{*}\right)$ as described by McPhee et al. (1999, 2016):

$H_{\mathrm{f}}=\rho_{\mathrm{sw}} c_{\mathrm{p}} c_{\mathrm{H}} u_{*} \delta_{\mathrm{T}}$,

where $\delta_{\mathrm{T}}=T-T_{\mathrm{f}}$, with $T\left({ }^{\circ} \mathrm{C}\right)$ the water temperature beneath the ice and $T_{\mathrm{f}}\left({ }^{\circ} \mathrm{C}\right)$ is the freezing point of saltwater calculated from salinity $S$ and pressure $p$ (dbar) as

$$
\begin{aligned}
T_{\mathrm{f}}= & -0.057 S+\left(1.710523 \times 10^{-3}\right) S^{1.5} \\
& -\left(2.154996 \times 10^{-4}\right) S^{2}-\left(7.53 \times 10^{-4}\right) p
\end{aligned}
$$

$C_{\mathrm{H}}$ is the bulk heat transfer coefficient $(0.0085)$ (Sirevaag 2009; McPhee et al. 2016) and $c_{\mathrm{w}}$ is the specific heat capacity of seawater $\left(3980 \mathrm{~J} \mathrm{~kg}^{-1}{ }^{\circ} \mathrm{C}^{-1}\right)$. Measurements of $S$, $T$, and $p$ were performed by the CTD probe at a depth of $0.5-1.0 \mathrm{~m}$ below the ice. The CTD sensors are accurate to within $\pm 0.0005 \mathrm{~S} \mathrm{~m}^{-1}$ for conductivity and to $\pm 0.005{ }^{\circ} \mathrm{C}$ for $T$. The $u_{*}$ was computed from the acoustic velocimeter data streams as the square root of the Reynolds stress magnitude (Berg et al. 2007). First, the streamwise (u), traverse $(v)$ and vertical $(w)$ velocity components were decomposed into mean and deviatory velocities as $u=\bar{u}+u^{\prime}, v=\bar{v}+v^{\prime}$, and $w=\bar{w}+w^{\prime}$. The $u_{*}$ was then derived as

$u_{*}=\left({\overline{u^{\prime} w^{\prime}}}^{2}+{\overline{v^{\prime} w^{\prime}}}^{2}\right)^{1 / 4}$.

The $u_{*}$ was computed as a function of the ensemble averaging interval where a time window of 15 min was deemed to be suitable for deriving $u_{*}$ (McPhee 2008).

Assuming that all of the excess under-ice heat went into melting ice, the computed $H_{\mathrm{f}}$ was used to estimate rates of ice melt $\left(h\right.$, in mm day $\left.{ }^{-1}\right)$ as

$h=\frac{H_{\mathrm{f}}}{\Delta H_{\mathrm{f}} \rho_{\mathrm{i}}}$

where $\Delta H_{\mathrm{f}}$ is the specific heat of fusion of ice ( $333.55 \mathrm{~kJ} \mathrm{~kg}^{-1}$ ), and $\rho_{\mathrm{i}}$ is the bulk density of ice (measured; bottom $10 \mathrm{~cm}=805-959 \mathrm{~kg} \mathrm{~m}^{-3}$ ). The melted ice volume was multiplied by 0.89 to compute meltwater volume released per unit area of sea-ice per day $\left(\mathrm{L} \mathrm{m}^{-2} \mathrm{day}^{-1}\right)$. The $\mathrm{O}_{2}$ flux rate due to basal thermodynamics $\left(T \mathrm{O}_{2 \mathrm{f}}\right)$ was then calculated by assuming that the released meltwater was anoxic and at a temperature of $0{ }^{\circ} \mathrm{C}$, consistent with the assumption of $\mathrm{O}_{2}$ - and salt-free parent ice (Glud et al. 2002). Every liter of anoxic meltwater released would thus appear within the measured $\mathrm{O}_{2}$ fluxes as an "uptake" of $456.6 \mu \mathrm{mol}$ $\mathrm{O}_{2}$ by the ice, representing the theoretical upper limit of $\mathrm{O}_{2}$ exchange at the ice-water interface due to basal ice formation or melt (Long et al. 2012). Since this analysis considers only basal ice melt, this approach provides a minimum estimate of the impact of meltwater on the measured eddy fluxes. 


\section{Results}

\section{Ice stations}

The land-fast ice station (DNB) had $115 \mathrm{~cm}$-thick sea-ice covered by $70 \mathrm{~cm}$ of snow. Freeboard was negative, resulting in an $8 \mathrm{~cm}$ slush snow layer at the snow-ice interface. Average air temperature for this campaign was $-25 \pm 10^{\circ} \mathrm{C}$.

The sampled stations between 82 and $85^{\circ} \mathrm{N}$ in the central Arctic (Ice 4, Ice 5 and Ice 6 ) were characterized by a heavily degraded first-year ice pack in advanced stages of melt, with sea-ice thickness frequently $<1.0 \mathrm{~m}$, ice coverage down to $50 \%$, and up to $50 \%$ melt-pond cover (Table 1 ). Average air temperature at these sites ranged from $0.3 \pm 0.6$ to $-3.2 \pm 0.5{ }^{\circ} \mathrm{C}$. In contrast, station Ice 7 consisted of a multi-year ice floe that was less degraded in comparison, and had a relatively homogenous ice thickness of $\sim 1.8 \mathrm{~m}$. Station Ice 7 was sampled in the second half of September, when air temperature was cooler and freezing conditions in melt ponds and leads were observed. In all cases, snow depth was $\leq 6 \mathrm{~cm}$ (Table 1 ).

The ice-associated phototrophic biomass at stations Ice 4 to Ice 7 consisted largely of diatoms within the ice matrix and melt ponds, and more conspicuously as aggregates in two distinct forms: (1) spherical aggregations composed mainly of pennate diatoms such as Nitzschia sp. and Navicula sp. and (2) filamentous strands of the centric diatom Melosira arctica attached to the underside of the ice (Fernández-Méndez et al. 2014). Under-ice aggregate abundance, quantified using ROV image surveys conducted within the vicinity (40-350 m distant) of our instrumented areas of each ice floe, ranged from 0.3 aggregates $\mathrm{m}^{-2}$ at Ice
5 to 3.8 aggregates $\mathrm{m}^{-2}$ at Ice 7 , with an estimated average biomass of 0.1-6.5 $\mathrm{mg} \mathrm{C} \mathrm{m}^{-2}$ (Katlein et al. 2014).

\section{Ice temperature, salinity and porosity}

Ice temperature ranged from -10 to $-0.1{ }^{\circ} \mathrm{C}$, with the coolest temperatures measured within the upper ice layers at DNB, and the warmest temperatures measured in the middle ice sections at Ice 5 (Fig. 2). Temperature within the bottom-ice layer was less variable and ranged from -1.1 to $-1.9^{\circ} \mathrm{C}$. Ice salinity was between 0.1 and 9.2. Brine volume calculated from ice $\mathrm{T}, \mathrm{S}$, and $\rho$ indicated high porosity at Ice 4, Ice 5, and Ice 6 above 0.1 and reaching as high as 0.4 at Ice 5 . Station Ice 7 was somewhat less variable with porosity values between 0.01 and 0.12 (Fig. 2).

\section{Oxygen microprofiles}

Under-ice microprofiling was attempted at stations Ice 3-6. Deploying the instrument correctly with the sensor tip positioned nearby the ice-water interface is an inherently difficult procedure due to the uneven underside of the ice floe, and the need to position the fragile sensors nearby the solid boundary without having an accurate visual reference aid. Successful measurements were made at stations Ice 3-5, and even here only single $\mathrm{O}_{2}$ microprofiles were collected, due to sensor damage incurred following contact of the sensor tip and/or penetration into the solid ice. Despite the challenges posed by this method, the available microprofiles for stations Ice 3-5 showed a consistent picture of steep $\mathrm{O}_{2}$ gradients at the ice-water interface and highly $\mathrm{O}_{2}$-depleted conditions within the ice (Fig. 3).
Table 1 Location and characteristics of the seaice stations investigated in Daneborg (DNB), North-east Greenland, and the central Arctic Ocean (stations Ice 4-7)

\begin{tabular}{llllll}
\hline Station name & DNB & Ice 4 & Ice 5 & Ice 6 & Ice 7 \\
\hline Station ID & DNB & PS80/3_277 & PS80/3_323 & PS80/3_335 & PS80/3_349 \\
Arrival date & $24 \mathrm{Mar}$ & $25 \mathrm{Aug}$ & 4 Sep & 7 Sep & 18 Sep \\
Latitude & $74^{\circ} 18.57^{\prime} \mathrm{N}$ & $82^{\circ} 52.95^{\prime} \mathrm{N}$ & $81^{\circ} 55.53^{\prime} \mathrm{N}$ & $85^{\circ} 06.11^{\prime} \mathrm{N}$ & $87^{\circ} 56.01^{\prime} \mathrm{N}$ \\
Longitude & $20^{\circ} 13.99^{\prime} \mathrm{W}$ & $130^{\circ} 7.77^{\prime} \mathrm{E}$ & $131^{\circ} 7.72^{\prime} \mathrm{E}$ & $122^{\circ} 14.72^{\prime} \mathrm{E}$ & $61^{\circ} 13.04^{\prime} \mathrm{E}$ \\
Ice thickness $(\mathrm{m})$ & 1.1 & 0.9 & 0.8 & 1.4 & 1.9 \\
Ice coverage $(\%)$ & 100 & 80 & 60 & 50 & 100 \\
Ice type & FI/FYI & PI/FYI & PI/FYI & PI/FYI & PI/MYI \\
Snow depth $(\mathrm{m})$ & 0.8 & $<0.01$ & 0.06 & 0.06 & 0.02 \\
Ice freeboard $(\mathrm{m})$ & -0.05 & 0.18 & 0.08 & 0.05 & 0.11 \\
Melt-pond cover $(\%)$ & 0 & 50 & 10 & 30 & 20 \\
Air temperature $\left({ }^{\circ} \mathrm{C}\right)$ & $-25 \pm 10$ & $-0.3 \pm 0.3$ & $-3.2 \pm 0.5$ & $-1.6 \pm 1.0$ & $-3.9 \pm 0.5$ \\
Wind velocity $\left(\mathrm{m} \mathrm{s}^{-1}\right)$ & $\mathrm{n} / \mathrm{a}$ & $1.7 \pm 1.1$ & $5.3 \pm 1.9$ & $7.5 \pm 3.1$ & $2.3 \pm 1.0$ \\
Ship drift $\left(\mathrm{m} \mathrm{s}^{-1}\right)$ & - & $0.11 \pm 0.03$ & $0.15 \pm 0.07$ & $0.15 \pm 0.10$ & $<0.01 \pm 0.02$ \\
Incoming PAR $\left(\mu \mathrm{mol} \mathrm{m}^{-2} \mathrm{~s}^{-1}\right)$ & $177 \pm 215$ & $108 \pm 87$ & $120 \pm 147$ & $50 \pm 44$ & $21 \pm 12$ \\
\hline
\end{tabular}

Above-ice environmental parameters are reported as mean $\pm \mathrm{SD}$ over the $\sim 2$ day duration of each ice station. Ice type is classified as land-fast ice (FI) or pack ice (PI), first-year ice (FYI) or multi-year ice (MYI) 
Fig. 2 Bulk ice measurements of temperature (a), salinity (b), porosity (c) at the five measurement sites

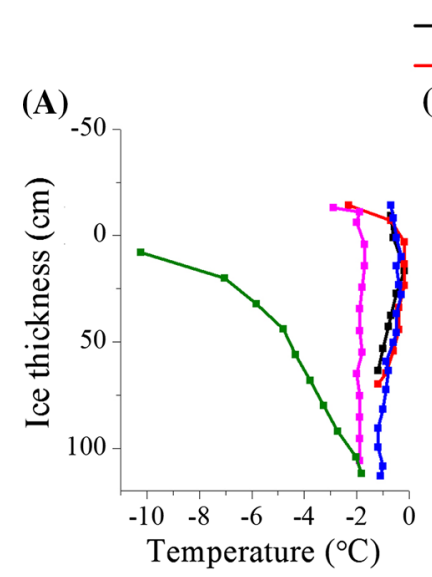

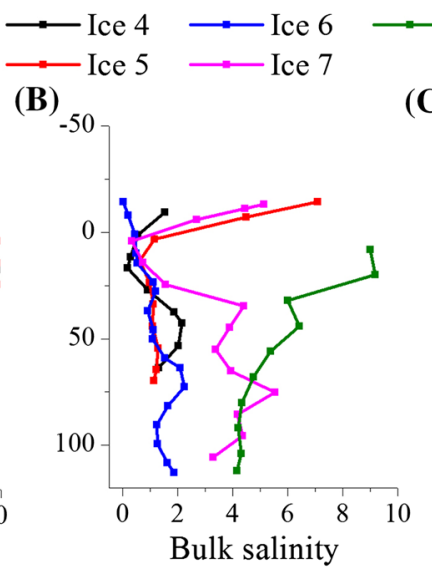

DNB

(C)

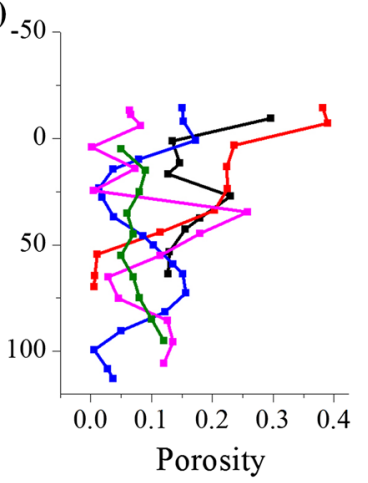

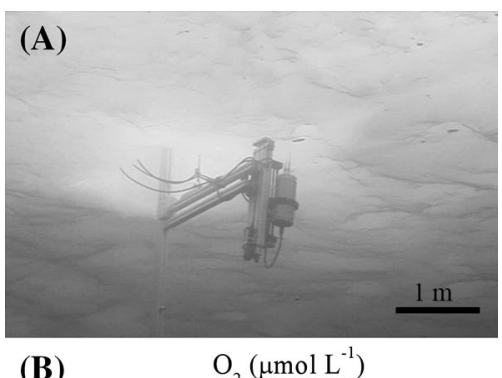

(B)

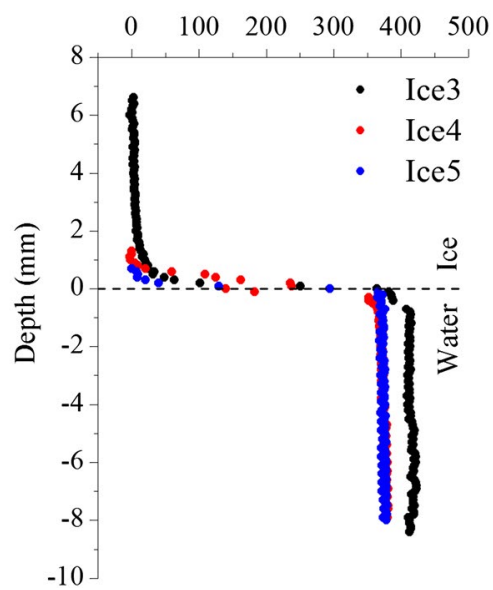

Fig. 3 The under-ice microprofiler (a) that was used to measure $\mathrm{O}_{2}$ concentration at the ice-water interface at three separate ice stations in the central Arctic Ocean (photo taken using the ROV). Steep $\mathrm{O}_{2}$ gradients were present at the ice-water interface at all three measurement sites (b). The sensor signal is likely to be impacted by contact with the solid ice

\section{Light environment}

Daily average incoming PAR was highest at DNB $\left(177 \pm 215 \mu \mathrm{mol} \mathrm{m} \mathrm{m}^{-2} \mathrm{~s}^{-1}\right)$ and at Ice 4 and Ice 5 $\left(\sim 100 \mu \mathrm{mol} \mathrm{m} \mathrm{m}^{-2} \mathrm{~s}^{-1}\right)$, decreasing to $50 \pm 44 \mu \mathrm{mol} \mathrm{m} \mathrm{m}^{-2} \mathrm{~s}^{-1}$ at Ice 6 and $21 \pm 12 \mu \mathrm{mol} \mathrm{m} \mathrm{m}^{-2} \mathrm{~s}^{-1}$ at Ice 7 (Table 1). PAR transmittance, expressed as a $\%$ of incoming PAR, was highest at Ice $4(13 \%)$ and lowest at DNB $(0.001 \%)$ (Table 2). Under-ice ROV measurements of light transmittance, available for Ice 5, Ice 6 and Ice 7, documented values that were highly variable on meter spatial scales (Fig. 4). The highest range in transmittance values was measured at Ice 6 (from $<0.1$ to $37.8 \%$; mean $\pm \mathrm{SD}=4.2 \% \pm 5.3$ $(n=2326)$, median $=1.7 \%$, mode $=1.3 \%)$, followed by Ice 5 (from $<0.1$ to $21.8 \%$; mean $\pm \mathrm{SD}=2.9 \% \pm 2.3(n=2177)$, median $=2.5 \%$, mode $=2.2 \%$ ), and Ice 7 (from 0.2 to $18.4 \%$; mean $\pm \mathrm{SD}=3.5 \% \pm 2.9(n=553)$, median $=2.5 \%$, mode $=1.2 \%$ ).

\section{Eddy-covariance $\mathrm{O}_{2}$ fluxes}

High-quality $\mathrm{O}_{2}$ fluxes were extracted from 81 to $96 \%$ of the collected AEC data. The DNB dataset consists of $62 \mathrm{~h}$ of continuous under-ice $\mathrm{O}_{2}$ flux measurements whereas the central Arctic Ocean data consist of shorter 20-41 h datasets with a total of $\sim 110 \mathrm{~h}$ of flux measurements divided between stations Ice 4-7. Well-developed turbulent conditions were evident at all five measurement locations, with the weighted spectra (i.e., the power spectral density multiplied by the wavenumber) of the vertical velocity variance showing a distinct peak in the area-preserving spectrum, as well as a fall-off to the $-2 / 3$ slope in the $\log -\log$ representation of the spectrum (McPhee 2008). Cumulative cospectra, computed for periods with high and low flow velocity, indicated a dominance of flux-contributing turbulent eddies within the frequency range of 0.0015 to $1 \mathrm{~Hz}$. Flux convergence occurred between $0.0015 \mathrm{~Hz}(\sim 660 \mathrm{~s})$ and $0.001 \mathrm{~Hz}(1000 \mathrm{~s})$, indicating that the selected averaging time scale of $900 \mathrm{~s}$ was optimal for flux extraction under the conditions we encountered (Lorke et al. 2013). Temporal misalignment between velocity and $\mathrm{O}_{2}$ concentration data streams that occurred due to sensor response time and sensor separation distances gave small errors in the flux estimates $(<10 \%)$, and this was corrected by shifting the $\mathrm{O}_{2}$ data in time relative to the $w$ data to compute the maximum numerical flux for $\overline{w^{\prime} O_{2}^{\prime}}(\mathrm{McGinnis}$ 
Table 2 Under-ice environmental parameters and fluxes (mean $\pm \mathrm{SD})$ for the five investigated locations

\begin{tabular}{|c|c|c|c|c|c|c|c|}
\hline Parameter & Symbol & Unit & DNB & Ice 4 & Ice 5 & Ice 6 & Ice 7 \\
\hline Transmitted PAR & $\mathrm{PAR}_{T}$ & $\mu \mathrm{mol} \mathrm{m} \mathrm{m}^{-2} \mathrm{~s}^{-1}$ & $0.2 \pm 0.2$ & $14 \pm 10$ & $3 \pm 3$ & $3 \pm 2$ & $1.7 \pm 0.9$ \\
\hline Mean flow velocity & $U$ & $\mathrm{~m} \mathrm{~s}^{-1}$ & $0.02 \pm 0.01$ & $0.03 \pm 0.01$ & $0.03 \pm 0.01$ & $0.10 \pm 0.05$ & $0.02 \pm<0.01$ \\
\hline Friction velocity & $u_{*}$ & $\mathrm{~cm} \mathrm{~s}^{-1}$ & $0.2 \pm 0.1$ & $0.2 \pm<0.1$ & $0.2 \pm<0.1$ & $0.5 \pm 0.2$ & $0.3 \pm<0.1$ \\
\hline Water temperature & $T$ & ${ }^{\circ} \mathrm{C}$ & $-1.71 \pm<0.01$ & $-1.57 \pm 0.02$ & $-1.62 \pm<0.01$ & $-1.56 \pm 0.01$ & $-1.80 \pm<0.01$ \\
\hline Salinity & $S$ & - & $31.32 \pm 0.05$ & $30.86 \pm 0.19$ & $30.46 \pm 0.01$ & $30.02 \pm 0.06$ & $33.11 \pm<0.01$ \\
\hline Freezing temperature & $T_{\mathrm{f}}$ & ${ }^{\circ} \mathrm{C}$ & $-1.70 \pm<0.01$ & $-1.67 \pm 0.01$ & $-1.65 \pm<0.01$ & $-1.62 \pm<0.01$ & $-1.80 \pm<0.01$ \\
\hline Temperature variance & $\sigma_{\mathrm{T}}$ & ${ }^{\circ} \mathrm{C}$ & $-0.01 \pm<0.01$ & $0.10 \pm 0.01$ & $0.03 \pm<0.01$ & $0.07 \pm 0.02$ & $<-0.01 \pm<0.01$ \\
\hline Ocean heat flux & $\mathrm{OHF}$ & $\mathrm{W} \mathrm{m}^{-2}$ & $1.2 \pm 0.6$ & $-7.8 \pm 2.6$ & $-2.0 \pm 0.7$ & $-10.9 \pm 3.9$ & $0.1 \pm 0.1$ \\
\hline Rate of basal ice melt & $h$ & $m m$ day $^{-1}$ & $-0.4 \pm 0.2$ & $2.5 \pm 0.8$ & $0.5 \pm 0.2$ & $3.1 \pm 1.1$ & $<-0.1 \pm<0.1$ \\
\hline
\end{tabular}

Negative fluxes indicate a flux directed towards the ice. Flow velocity is measured by the velocimeter $0.5 \mathrm{~m}$ beneath the ice

(A)

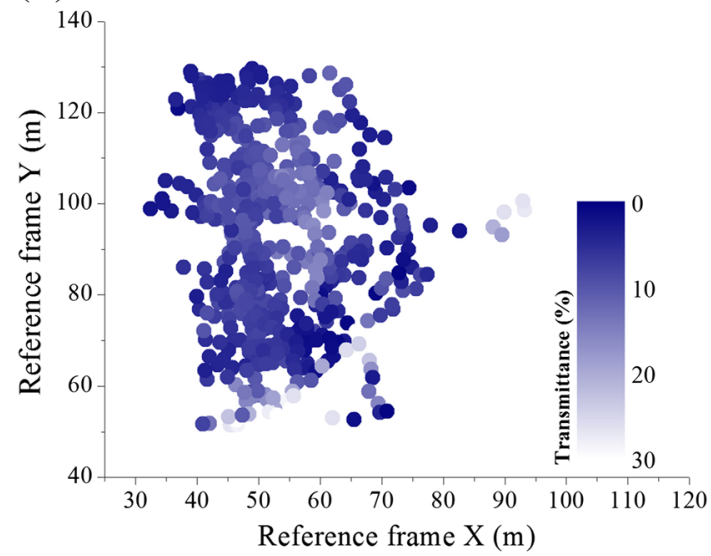

Fig. 4 PAR transmittance values as measured by the ROV at Ice 6 indicate a heterogeneous light environment due to the heavily ponded and deformed ice pack (a). Frequency distribution analyses (b) sug-

et al. 2008). A time shift of 0.2-0.8 s was applied for this correction, which is in good agreement with the response time of the $\mathrm{O}_{2}$ a sensors we used (Donis et al. 2015). Further evidence of well-developed turbulence and high-quality flux data was deduced from analysis of the cumulative instantaneous flux $w^{\prime} O_{2}^{\prime}$, where linear trends indicate a stable flux signal (Fig. 5) (Berg et al. 2003; Long et al. 2012).

Average AEC $\mathrm{O}_{2}$ fluxes were directed towards the ice (negative values) at all five stations, indicating an uptake of $\mathrm{O}_{2}$ by the ice environment. Mean $( \pm \mathrm{SD})$ fluxes ranged from $-2.3 \pm 8.0 \mathrm{mmol} \mathrm{O}_{2} \mathrm{~m}^{-2} \mathrm{day}^{-1}$ at DNB to $-6.2 \pm 3.7 \mathrm{mmol}$ $\mathrm{O}_{2} \mathrm{~m}^{-2}$ day $^{-1}$ at Ice 5 (Table 3 ). The flow velocity magnitude was the predominant driver of the $\mathrm{O}_{2}$ fluxes at four of the five sites, with higher flow velocities resulting in higher $\mathrm{O}_{2}$ uptake rates by the ice (Figs. 5, 6). The flow velocity, which in turn showed broad agreement in dynamics with the wind velocity, explained up to $92 \%$ of the hourly variations in the $\mathrm{O}_{2}$ fluxes (Fig. 6).
(B)

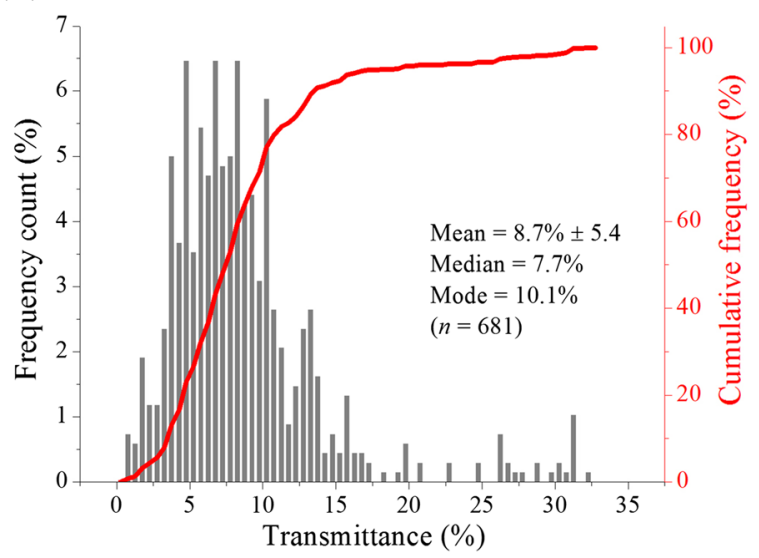

gest clustering of transmittance values at around $8-10 \%$ for this particular dataset, depending on the method used to describe the average

\section{Eddy-covariance estimates of sea-ice primary productivity}

A tight coupling between the measured AEC $\mathrm{O}_{2}$ fluxes and PAR availability, as one would expect due to photosynthetic production, was not immediately apparent at any of the investigated ice stations. Instead, the AEC fluxes at stations Ice 4-7 were significantly correlated to the water flow velocity, which masked any potential primary production effects. We excluded the flow velocity effects from the eddy fluxes by subtracting the relationship between the eddy fluxes and the flow velocity magnitude we established for each dataset (Fig. 6). Following this adjustment, patterns consistent with photosynthetic production were only evident at Ice 4, which is the study site where we observed the highest transmitted PAR values (Fig. 7, Table 2). Interestingly, the adjusted $\mathrm{O}_{2}$ fluxes followed PAR dynamics. A modified photosynthesis-irradiance (P-E) curve fitted to the data $\left(R^{2}=0.40\right)$ suggested that light saturation $\left(E_{\mathrm{k}}\right.$ value $)$ 

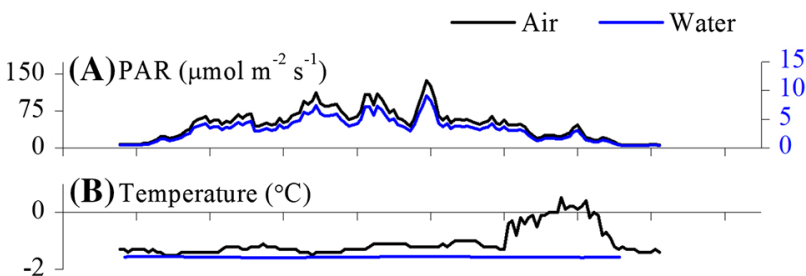

20 (C) Velocity magnitude

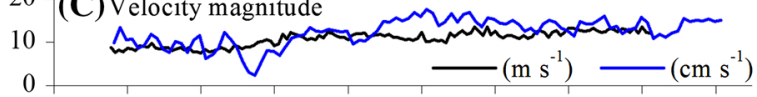

$10\urcorner$ (D) $\mathrm{O}_{2}$ flux $\left(\mathrm{mmol} \mathrm{m}^{-2} \mathrm{~d}^{-1}\right)$

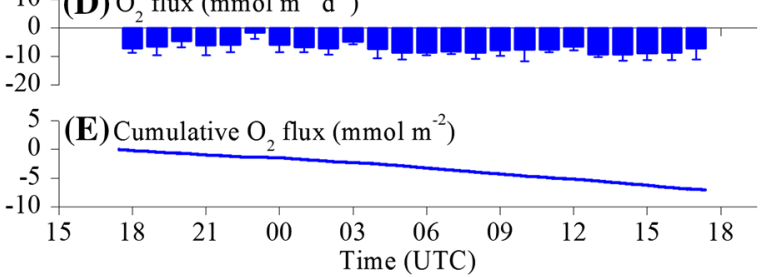

Fig. 5 A $\sim 24 \mathrm{~h}$ time series of environmental conditions above and below the ice [PAR (a), temperature (b), flow velocity (c)] and underice eddy-covariance $\mathrm{O}_{2}$ fluxes (d) in the central Arctic Ocean at station Ice 6. Linear cumulative instantaneous $\mathrm{O}_{2}$ fluxes (e) indicate a good flux signal. Error bars are SD $(n=4)$. Negative fluxes indicate oxygen uptake by the ice occurred above $16 \mu \mathrm{mol}$ PAR $\mathrm{m}^{-2} \mathrm{~s}^{-1}$, and no photo inhibition was observed up to maximum transmitted light levels of $36 \mu \mathrm{mol} \mathrm{PAR} \mathrm{m}^{-2} \mathrm{~s}^{-1}$ (Fig. 7). By assuming that (a) gross primary productivity under the lowest irradiance level

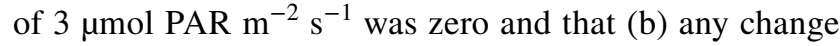
in $\mathrm{O}_{2}$ release under higher irradiance relative to that zero point was caused by photosynthetic production, we can estimate the daily primary productivity rate at Ice 4 as the mean $( \pm \mathrm{SD})$ of all of the daytime hourly fluxes, which is $1.3 \pm 0.9 \mathrm{mmol} \mathrm{O}_{2} \mathrm{~m}^{-2} \mathrm{day}^{-1}(n=17)$.

\section{Laboratory measurements of autotrophic and heterotrophic activity}

Sea-ice bacterial $\mathrm{C}$ demand rates ranged from 0.003 to $0.166 \mathrm{mmol} \mathrm{C} \mathrm{m}^{-2} \mathrm{day}^{-1}$, with the highest value being measured at DNB on land-fast ice during winter. Ice primary productivity rates ranged from 0.008 to $0.125 \mathrm{mmol} \mathrm{C} \mathrm{m}^{-2} \mathrm{day}^{-1}$. Ice primary productivity values for the central Arctic Ocean were obtained from Fernández-Méndez et al. (2015). The laboratory measurements indicate an overall net heterotrophic ice habitat at DNB $\left(-0.155 \mathrm{mmol} \mathrm{C} \mathrm{m}^{-2} \mathrm{day}^{-1}\right)$, whereas the ice at the four

Table 3 Eddy-covariance fluxes beneath the ice and estimated rates of biological activity within the ice

\begin{tabular}{|c|c|c|c|c|c|c|c|}
\hline Parameter & Symbol & Unit & DNB & Ice 4 & Ice 5 & Ice 6 & Ice 7 \\
\hline Eddy-covariance $\mathrm{O}_{2}$ flux & AEC & $\mathrm{mmol} \mathrm{O}_{2} \mathrm{~m}^{-2}$ day $^{-1}$ & $-2.3 \pm 8.0$ & $-3.5 \pm 3.0$ & $-6.2 \pm 3.7$ & $-5.8 \pm 3.5$ & $-3.2 \pm 3.6$ \\
\hline Bacterial C demand & BP & mmol C m${ }^{-2}$ day $^{-1}$ & 0.166 & 0.006 & 0.006 & 0.003 & 0.062 \\
\hline Primary production* & PP & mmol C m ${ }^{-2}$ day $^{-1}$ & 0.011 & 0.033 & 0.008 & 0.017 & 0.125 \\
\hline Auto-heterotroph balance & BP-PP & $\mathrm{mmol} \mathrm{C} \mathrm{m}^{-2} \mathrm{day}^{-1}$ & -0.155 & 0.027 & 0.002 & 0.014 & 0.063 \\
\hline $\begin{array}{l}\text { Thermodynamic-induced } \mathrm{O}_{2} \\
\text { flux (basal) }\end{array}$ & $T \mathrm{O}_{2 \mathrm{f}}$ & $\mathrm{mmol} \mathrm{O}_{2} \mathrm{~m}^{-2}$ day $^{-1}$ & $0.2 \pm 0.1$ & $-1.1 \pm 0.4$ & $-0.2 \pm 0.1$ & $-1.4 \pm 0.5$ & $0.0 \pm 0.0$ \\
\hline
\end{tabular}

*Values for the central Arctic Ocean (Ice 4-7) are from Fernández-Méndez et al. (2015)

Fig. 6 Relationship between the under-ice flow velocity magnitude and the eddy-covariance $\mathrm{O}_{2}$ fluxes for the complete datasets at the four measurement sites in the central Arctic (Ice 4-7, panels a-d) and for the site in Greenland (Daneborg, panel e). The solid red line is a linear regression fitted to the data. Broken lines are the 95\% confidence bands. Negative fluxes indicate uptake by the ice
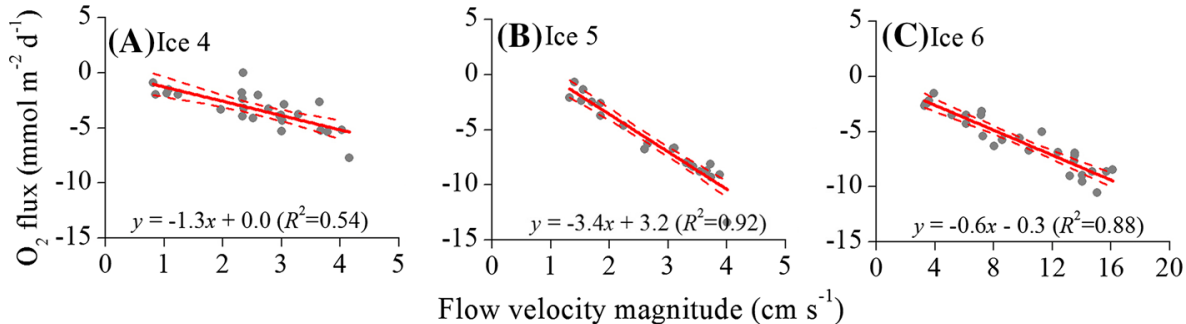

Flow velocity magnitude $\left(\mathrm{cm} \mathrm{s}^{-1}\right)$

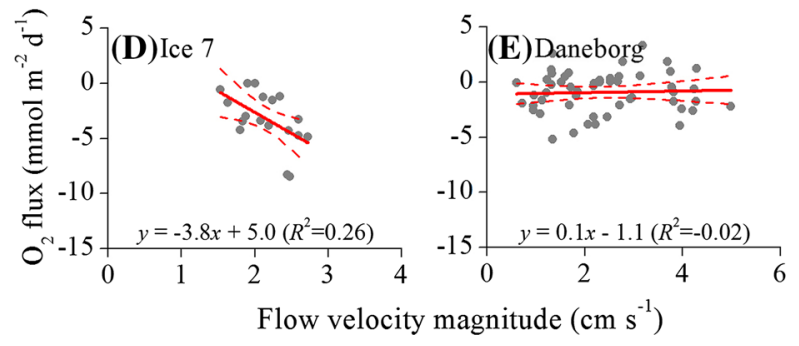



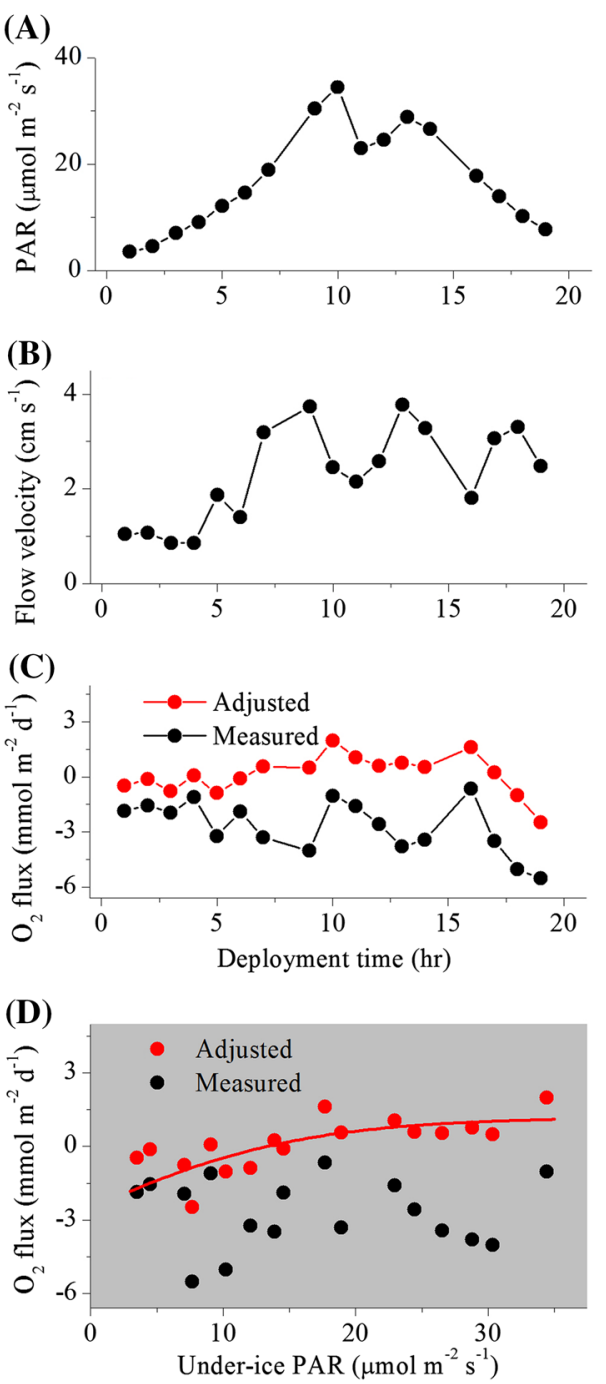

Fig. 7 A 17 h time series at Ice 4 of a under-ice PAR availability, b water flow velocity, and c eddy-covariance $\mathrm{O}_{2}$ fluxes before (black) and after (red) subtracting the effects of flow velocity. Eddy fluxes versus light availability for the same data before and after adjustment (d). The fitted modified P-E relationship $\left(R^{2}=0.40\right)$ had a maximum rate of primary productivity $\left(P_{\mathrm{m}}\right)$ of $3.7 \mathrm{mmol} \mathrm{O}_{2} \mathrm{~m}^{-2}$ day $^{-1}$ and a light saturation $\left(E_{\mathrm{k}}\right)$ value of $16 \mu \mathrm{mol}$ PAR m $\mathrm{m}^{-2} \mathrm{~s}^{-1}$

stations in the central Arctic Ocean was net autotrophic (up to $0.07 \mathrm{mmol} \mathrm{C} \mathrm{m}^{-2} \mathrm{day}^{-1}$; Table 3).

\section{Heat fluxes, ice melt rate and physical-induced $\mathrm{O}_{2}$ exchange}

Average $H_{\mathrm{f}}$ ranged from $-10.9 \pm 3.9 \mathrm{~W} \mathrm{~m}^{-2}$ at Ice 6 to $1.2 \pm 0.6 \mathrm{~W} \mathrm{~m}^{-2}$ at DNB (Table 2). The direction of the flux is indicated by its preceding sign, where negative values indicate an uptake of heat by the ice. The ocean was a source of heat to the ice at stations Ice 4-6, with temperature variance $\left(\sigma_{T}\right)$ highest at Ice $4\left(0.10 \pm 0.01{ }^{\circ} \mathrm{C}\right)$ and lowest at Ice $5\left(0.03 \pm<0.01{ }^{\circ} \mathrm{C}\right.$; Table 2$)$. Assuming that all the excess heat went into melting ice, the rate of ice melt at Ice 6 was $\sim 3 \mathrm{~mm} \mathrm{day}^{-1}$ and for station Ice 5 it was $\sim 0.5 \mathrm{~mm} \mathrm{day}^{-1}$. In contrast to this, supercooled waters were found at Ice 7 and DNB, with average $\sigma_{T}$ of up to $-0.01 \pm<0.010{ }^{\circ} \mathrm{C}$ and thus potential for ice growth. Estimated heat fluxes were low $\left(-0.1\right.$ to $\left.-1.2 \mathrm{~W} \mathrm{~m}^{-2}\right)$ as were rates of ice growth (negative melt equals growth; $<0.5 \mathrm{~mm} \mathrm{day}^{-1}$ ). Estimates of the $\mathrm{O}_{2}$ exchange rate due to bottom-ice growth or decay were computed from the $H_{\mathrm{f}}$ to investigate the potential imprint of thermodynamic (physical) processes on the $\mathrm{O}_{2}$ flux at the ice-water interface as measured by AEC (Long et al. 2012). The $\mathrm{O}_{2}$ flux due to basal ice melt was estimated to be a minor component, accounting for a maximum of $30 \%$ of the difference between the AEC flux magnitude and laboratory measures of biotic activity (Table 3 ).

\section{Discussion}

\section{$\mathrm{AEC}_{2}$ fluxes: biological versus physical contributions}

This study employs AEC and laboratory incubation techniques to assess autotrophic and heterotrophic productivity in sea-ice across a broad range of ice types and environmental conditions, from land-fast ice during winter to first-year and multi-year ice floes in the central Arctic Ocean during summer. This dataset constitutes an opportunity to investigate the rates and drivers of $\mathrm{O}_{2}$ fluxes at the sea ice-water interface as measured using AEC, and the extent to which these measurements represent biological versus physical processes.

To date, applications of the AEC method in the Arctic have mostly focused on seafloor ecosystems. Here, the method constitutes a strong tool for quantifying primary productivity, respiration, and the net ecosystem metabolism rates non-invasively across complex and hard benthic surfaces that characterize much of the Arctic coastal zone (Glud et al. 2010; Attard et al. 2014, 2016). Sea-ice represents a challenge for metabolism studies similar to hard benthic surfaces, in that the underside of the ice pack is a solid, often uneven surface with a patchy distribution of biotic communities (Rysgaard et al. 2001; Katlein et al. 2014; Lange et al. 2016). The AEC approach could therefore be a highly beneficial tool and would complement other methods in sympagic productivity investigations. While overcoming the inherent challenges of incubation approaches, as well as other approaches that rely upon extraction of ice samples for analysis, the $\mathrm{O}_{2}$ fluxes as measured by AEC beneath the ice are complicated by ice thermodynamics and meltwater discharge, whereby biological $\mathrm{O}_{2}$ production or consumption may be masked by a much larger physical-induced flux under conditions of freezing or melting (Glud et al. 2014; 
Else et al. 2015). In this study, the AEC fluxes consistently suggested $\mathrm{O}_{2}$ uptake rates by the ice environment at the 5 different study locations ranging from $-2.3 \mathrm{mmol} \mathrm{O}_{2} \mathrm{~m}^{-2}$ day $^{-1}$ at DNB to $-6.2 \mathrm{mmol} \mathrm{O}_{2} \mathrm{~m}^{-2}$ day $^{-1}$ at Ice 5 (Table 3). These rates are 1-3 orders of magnitude higher than those of bacterial $\mathrm{C}$ demand performed on the same ice floes (range from 0.003 to $0.166 \mathrm{mmol} \mathrm{C} \mathrm{m}^{-2} \mathrm{day}^{-1}$; Table 3), the latter at the lower end of bacterial $\mathrm{C}$ demand rate estimates for sea-ice in Greenland and in the Fram Strait (range from 0.06 to $3.37 \mathrm{mmol} \mathrm{C} \mathrm{m}^{-2} \mathrm{day}^{-1}$ ) (Søgaard et al. 2010, 2013; Kaartokallio et al. 2013; Glud et al. 2014). Similar inconsistencies between the laboratory and in situ techniques are identified for the resolved autotrophic-heterotrophic balance of the ice floes: whereas AEC measurements suggest an uptake of $\mathrm{O}_{2}$ by the ice environment, laboratory measures suggest net autotrophy at stations Ice 4-7 (Table 3). Differences between the two methodologies employed are clear and may account for variations in the resolved rates; however, the magnitude and direction of the $\mathrm{AEC}_{2}$ fluxes are consistent with a release of $\mathrm{O}_{2}$-deplete meltwater. Under-ice microprofile measurements documented steep $\mathrm{O}_{2}$ gradients at the ice-water interface (Fig. 3), with the gradient direction being in agreement with the $\mathrm{O}_{2}$ flux directed towards the ice as measured using AEC, and confirms other microsensor measurements performed in melting sea-ice (Kuhl et al. 2001; Glud et al. 2002). Meltwater $\mathrm{O}_{2}$ fluxes have the same sign (direction) as heterotrophic processes in the ice, so the AEC fluxes measured during dark would represent the sum of these two processes. During daytime, photosynthetic $\mathrm{O}_{2}$ production would offset the $\mathrm{O}_{2}$ uptake rate, but the primary productivity rate in the investigated ice floes is likely to be smaller than the sum of meltwater- and respiration-driven $\mathrm{O}_{2}$ flux, resulting in an overall "uptake" of $\mathrm{O}_{2}$ by the bottom-ice environment over $24 \mathrm{~h}$ as measured using AEC. Glud et al. (2014) made similar observations for melting pack ice in the Fram Strait. Despite a significant ice-associated primary production and light-dependent $\mathrm{O}_{2}$ exchange dynamics at this site, under-ice fluxes as measured by AEC suggested a net uptake of $\mathrm{O}_{2}$ by the ice environment of $8 \mathrm{mmol} \mathrm{O}_{2} \mathrm{~m}^{-2}$ day $^{-1}$ due to a large $\left(\sim 25 \mathrm{~L} \mathrm{~m}^{-2} \mathrm{day}^{-1}\right)$ meltwater flux. Reliable estimates of heterotrophic activity in sea-ice quantified using AEC would thus require accurate measurements of meltwater-driven $\mathrm{O}_{2}$ flux.

Within the marginal ice zone of the central Arctic Ocean $\left(\sim 82-84^{\circ} \mathrm{N}\right)$, drifting of ice floes into warmer water result in large ice-water $H_{\mathrm{f}}$ of $>100 \mathrm{~W} \mathrm{~m}^{-2}$ and rapid bottom ablation rates of several $\mathrm{cm} \mathrm{day}^{-1}$ (McPhee et al. 1987; Perovich et al. 1989; Peterson et al. 2017). The effect of such a large release of $\mathrm{O}_{2}$-depleted meltwater could bias the $\mathrm{O}_{2}$ fluxes as measured by AEC by $>10 \mathrm{mmol} \mathrm{O}_{2}$ $\mathrm{m}^{-2}-$ day $^{-1}$ (Glud et al. 2014). However, during our study, maximum temperature variance $\left(\sigma_{T}\right)$ was $0.10{ }^{\circ} \mathrm{C}$ and $H_{\mathrm{f}}$ were in all cases $<11 \mathrm{~W} \mathrm{~m}^{-2}$, with comparatively low bottom-ice ablation rates of $\leq 3 \mathrm{~mm} \mathrm{day}^{-1}$ resulting in maximum physical-induced $\mathrm{O}_{2}$ exchange rates $<1.5 \mathrm{mmol}$ $\mathrm{O}_{2} \mathrm{~m}^{-2}$ day $^{-1}$ (Tables 2,3). This analysis suggests that ice melt from below was not a major contributor to the AEC $\mathrm{O}_{2}$ fluxes during our measurement period (Table 3), and that other processes not included in this analysis must be important. Absorption of solar radiation by the ice, ice cracks, meltwater in ponds, and surface water in open leads can have a big impact on the heat and mass balance of sea-ice (Eicken et al. 2002; Hudson et al. 2013). This is likely to be an important process not accounted for in our calculations. Heat fluxes associated with drainage, advection, and convection of warm meltwater may exceed the net solar shortwave flux, with wind stress helping to sustain fluid flow into ice neighboring a pond or lead (Eicken et al. 2002). The meltwater would accumulate on the surface as melt ponds, or drain through the ice matrix and fill the pore spaces, ultimately accumulating beneath the ice and exchanging with underlying waters. Ice temperatures around $0{ }^{\circ} \mathrm{C}$ were evident at several of the ice stations in the central Arctic Ocean, particularly within the upper layers of the ice, and melt-pond cover was between 10 and $50 \%$. Ice porosity was frequently above 0.20 and as high as 0.40 at Ice 5 (Fig. 2). These values are much higher than the critical brine volume fraction of $\sim 5 \%$ (porosity of $\sim 0.05$ ) that typically marks the transition from impermeable to permeable sea-ice (Golden et al. 1998), indicating that these ice layers are potentially a large reservoir for meltwater, and are susceptible to extensive advective and convective meltwater exchange. Aside from the effects on the measured AEC fluxes, the $\mathrm{O}_{2}$-depleted meltwater within the ice could be of considerable ecological significance for microbes and fauna living within the ice matrix (Kiko et al. 2017; Sørensen et al. 2017).

It is conceivable that accumulation and draining of meltwater may not be at steady-state, and that meltwater accumulation and release at the ice-water interface may not necessarily represent the surface ice melt rate during the period of assessment. Future studies would benefit from better constraining the meltwater flux. This could be achieved by performing AEC measurements of conductivity (salt) fluxes alongside temperature and $\mathrm{O}_{2}$ (Else et al. 2015). More important, however, would be to target periods when the ice is at or near steady-state. It is evident from our measurements, and from those by Glud et al. (2014) and Else et al. (2015), that variations in the $\mathrm{O}_{2}$ fluxes due to physical effects can by far exceed biotic $\mathrm{O}_{2}$ production and consumption rates when performed under dynamic ice growth or melt, which complicates flux interpretation. 


\section{AEC and laboratory measurements of ice algae primary productivity}

A tight coupling between the measured $\mathrm{AEC}_{2}$ fluxes and PAR availability, as one would expect due to photosynthetic production, was not immediately apparent at any of the investigated ice stations. Instead, the AEC fluxes at Ice 4-7 were significantly correlated to the water flow velocity, with $R^{2}$ values of up to 0.92 at Ice 5 (Fig. 6). Although higher flow velocities increased $H_{\mathrm{f}}$ to the underside of the ice, the magnitude change in $H_{\mathrm{f}}$, and the corresponding increase in bottom-ice melt rates, could only explain a very small fraction of the $\mathrm{O}_{2}$ flux increase seen in the AEC measurements. This analysis suggests that basal melt had minimal effects on the eddy fluxes. Instead, we postulate that higher wind and higher interface water flow velocities would increase transport and mixing of warm meltwater into neighboring ice, stimulating ice melt as well as meltwater exchange between meltwater reservoirs and the underlying waters. Excluding this effect from the measured fluxes should, therefore, take into account additional meltwater effects not accounted for in the basal melt estimates, and would get us closer to the biological fluxes required to quantify ice productivity. We are not able to accurately constrain the magnitude of the icemelt driven $\mathrm{O}_{2}$ fluxes using the present dataset, as this would require an additional extensive assessment of the various meltwater reservoirs, their $\mathrm{O}_{2}$ content, and their exchange dynamics. However, excluding the effects of processes that facilitate meltwater exchange, such as changes in water flow velocity, could help reveal biologically-mediated activity. This approach has previously been applied to highly permeable seafloor sediment deposits that experience extensive pore-water exchange under increased water flow velocities (Berg et al. 2013). Despite the uncertainties pertaining to the physically-induced $\mathrm{O}_{2}$ flux contribution in the AEC fluxes, we are not aware of other processes unrelated to photosynthetic production that could give similar $\mathrm{O}_{2}$ flux dynamics, which gives us confidence in this approach. After excluding the effects of flow velocity by subtracting the established flow-flux relationships from the measured AEC $\mathrm{O}_{2}$ fluxes, patterns consistent with photosynthetic production were evident at Ice 4 , which was the study site where we observed the highest transmitted PAR values and thus expected the strongest photosynthetic production signal. Similar patterns were not evident in the other datasets, possibly due to the reduced light availability in the bottomice environment when compared to Ice 4 (Table 2). Following adjustment, the $\mathrm{O}_{2}$ fluxes at Ice 4 clearly followed transmitted PAR dynamics, and a P-E relationship fitted to the data suggests a low-light adapted sympagic phototrophic community with a $E_{\mathrm{k}}$ of $16 \mu \mathrm{mol}$ PAR $\mathrm{m}^{-2} \mathrm{~s}^{-1}$, no photo inhibition under maximum observed irradiances of $36 \mu \mathrm{mol} \mathrm{PAR} \mathrm{m}^{-2} \mathrm{~s}^{-1}$, and maximum primary productivity rate $P_{\mathrm{m}}=3.7 \mathrm{mmol} \mathrm{O}_{2} \mathrm{~m}^{-2}$ day $^{-1}$ (Fig. $7 \mathrm{~d}$ ). The resulting values are somewhat higher than those obtained by Long et al. (2012) for land-fast ice in spring, similarly quantified using the AEC method $\left(P_{\mathrm{m}}=\sim 1.7 \mathrm{mmol} \mathrm{O}_{2} \mathrm{~m}^{-2}\right.$ day $^{-1}$, $E_{\mathrm{k}}=4.2 \mu \mathrm{mol}$ PAR $\left.\mathrm{m}^{-2} \mathrm{~s}^{-1}\right)$. The estimated daily primary productivity rate at Ice 4 of $1.3 \pm 0.9 \mathrm{mmol} \mathrm{O}_{2} \mathrm{~m}^{-2}$ day $^{-1}$ is substantially larger than laboratory estimates for the same ice floe $\left(0.03 \mathrm{mmol} \mathrm{O}_{2} \mathrm{~m}^{-2} \mathrm{day}^{-1}\right)$, and indeed much larger than all the laboratory-derived productivity estimates for the two sampling campaigns (range of 0.011-0.125 mmol $\mathrm{O}_{2}$ $\mathrm{m}^{-2}$ day $^{-1}$; Table 3 ). Primary productivity values reported for Arctic sea-ice range from 0.003 to $39 \mathrm{mmol} \mathrm{C} \mathrm{m}^{-2}$ day $^{-1}$ (Glud et al. 2007; Søgaard et al. 2010, 2013; Long et al. 2012; Fernández-Méndez et al. 2015; Arrigo 2017), with $\sim 75 \%$ of the reported values $\leq 5 \mathrm{mmol} \mathrm{C} \mathrm{m}^{-2} \mathrm{day}^{-1}$ and $\sim 50 \%$ of the reported values $\leq 1.3 \mathrm{mmol} \mathrm{C} \mathrm{m}^{-2} \mathrm{day}^{-1}$ (global mean $\pm \mathrm{SD}=4.0 \pm 6.4 \mathrm{mmol} \mathrm{C} \mathrm{m}{ }^{-2}$ day $^{-1}(n=86)$, mode $=5.7 \mathrm{mmol} \mathrm{m}^{-2} \mathrm{day}^{-1}$ ). Assuming an $\mathrm{O}_{2}: \mathrm{C}$ of 1.0 for comparison purposes, the ice primary productivity rates obtained in this study thus are at the lower end of literature values, but compare well in magnitude to about half of the existing rate estimates for Arctic sea-ice.

It is reasonable to assume that the magnitude of the AECderived primary productivity rate is correct, despite it being much larger than the corresponding laboratory-derived estimate. Large deposits of ice algae aggregates were observed on the seabed during this expedition, and at Ice 4 the deposition was estimated to be $5 \mathrm{~g} \mathrm{C} \mathrm{m}^{-2}$ (Boetius et al. 2013). Assuming a growth season of $90 \mathrm{~d}$ prior to our arrival at this location, the net primary productivity rate required for this biomass alone to accumulate would require average daily rates of about $5 \mathrm{mmol} \mathrm{C} \mathrm{m}{ }^{-2} \mathrm{day}^{-1}$. The ability of the AEC method to integrate over a large surface area of the bottomice habitat that includes sparsely-distributed algal aggregates and encrustations is likely to be an important factor in resolving reliable areal rates of sea-ice primary productivity. In turn, this will enable assessment of the importance of seaice productivity for biogeochemical fluxes in ice-covered regions and in sustaining pelagic and benthic ecosystems in the Arctic Ocean.

\section{Correlating AEC fluxes to transmitted PAR}

AEC measurements integrate a large surface area of the under-ice habitat. The so-called flux 'source area' or 'footprint', which is defined as the under-ice surface area that contributes $90 \%$ of the flux, was estimated using the conservative tracer tracking models by Berg et al. (2007) to be $\sim 290 \mathrm{~m}^{2}$ (length $=112 \mathrm{~m}$, width $=3.3 \mathrm{~m}$, and a region of maximum flux contribution located $\sim 5 \mathrm{~m}$ upstream from the instrument). While it is highly valuable to correlate AEC fluxes to transmitted PAR, the ability to obtain a PAR transmittance value that is representative of the AEC footprint 
area is challenging, because light transmittance may be highly variable on spatial scales of tens of meters (Fig. 4) (Nicolaus and Katlein 2013). Under-ice ROV measurements can adequately capture this spatial variability, and an average AEC footprint transmittance may then be expressed as the mean, median, or modal value, and the range of variability of these measurements (Fig. 4). In the absence of ROV measurements, above-ice (incoming) PAR would provide useful information on the environmental conditions during sampling.

\section{Outlook and recommendations for future research}

The AEC method is in many ways well-placed to investigate sea-ice metabolism. Using this method we have shown that considerable new insight about under-ice $\mathrm{O}_{2}$ flux dynamics and its drivers can be gained. In one case it was possible to derive algal productivity estimates under unaltered environmental conditions and for a large surface area of the underice environment. AEC estimates of algal productivity were substantially higher than those from traditional laboratory incubations, potentially highlighting the importance of performing productivity measurements under in situ conditions, as well as including a large surface area of the under-ice environment that includes sparsely-distributed algae encrustations and aggregates. Because AEC measurements integrate a large surface area of the ice, and thus include spatial variability in light and biomass, it is useful to consider variability in light transmittance on similar scales as that of the eddy footprint when correlating the AEC fluxes with PAR.

The AEC measurements also document considerable influence from physical processes, which we interpret as being due to meltwater accumulation and transport within and beneath the ice, and exchange with the underlying waters. Constraining the meltwater flux contribution to the $\mathrm{AEC}_{2}$ fluxes is not trivial. Meltwater accumulation and draining may not be at steady-state. Ice melt may occur from above as well as from below, and the portion of the AEC flux that is due to meltwater exchange may be many times larger than that from biological production and respiration. Targeting periods in time when the ice is close to steady-state will provide the best opportunities for $\mathrm{AEC}_{2}$ flux studies. Overall, and when considering the assumptions invoked in traditional ice productivity assessment methodologies, the AEC method represents a promising new tool for sea-ice metabolism studies. Further development of the method and inclusion of additional sensors and observations of sea-ice mass balance will provide well-constrained estimates of ice productivity.

Acknowledgements We would like to acknowledge expedition leader Prof. Antje Boetius and the captain and crew of the R/V Polarstern (ARK27-3, IceArc) for excellent logistics support and planning during the IceArc ARK27-3 expedition to the central Arctic Ocean. Axel Nordhausen, Steffen Jescheniak and Jörn Patrick Meyer provided valuable technical assistance during this expedition. Martin Schiller and Marcel Nicolaus supported ROV operations. We are grateful to Kunuk Lennert, Ivali Lennert, and Egon Frandsen for their expert help with solving technical issues, and with logistics planning during the Greenland expedition. Anni Glud (SDU) and the microsensor technicians at the Max Planck Institute for Marine Microbiology constructed the microsensors used in this study. This research was supported by grants from the Commission for Scientific Research in Greenland (KVUG GCRC6507), the Danish National Research Council (FNU 701400078B), the European Research Council through an Advanced Grant (HADES), the Horizon 2020 Research and Innovation Program (grant agreement number 669947), the Canada Excellence Research Chair (CERC) Program, the Arctic Science Partnership (ASP) Program, the Alfred-Wegener-Institut Helmholtz-Zentrum für Polar- und Meeresforschung (PACES program), the Max Planck Society, the Academy of Finland (project ID 294853), and the Walter and Andrée de Nottbeck Foundation. We are grateful to Prof Andrew McMinn and two anonymous reviewers for providing constructive comments that improved this manuscript.

\section{Compliance with ethical standards}

Conflict of interest The authors declare no conflict of interest.

Open Access This article is distributed under the terms of the Creative Commons Attribution 4.0 International License (http://creativeco mmons.org/licenses/by/4.0/), which permits unrestricted use, distribution, and reproduction in any medium, provided you give appropriate credit to the original author(s) and the source, provide a link to the Creative Commons license, and indicate if changes were made.

\section{References}

Arrigo KR (2014) Sea-ice ecosystems. Annu Rev Mar Sci 6:439-467. https://doi.org/10.1146/annurev-marine-010213-135103

Arrigo KR (2017) Sea-ice as a habitat for primary producers. In: Seaice. Wiley, Hoboken, pp 352-369. https://doi.org/10.1002/97811 18778371.ch14

Attard KM, Glud RN, McGinnis DF, Rysgaard S (2014) Seasonal rates of benthic primary production in a Greenland fjord measured by aquatic eddy correlation. Limnol Oceanogr 59:1555-1569. https ://doi.org/10.4319/lo.2014.59.5.1555

Attard KM, Stahl H, Kamenos NA, Turner G, Burdett HL, Glud RN (2015) Benthic oxygen exchange in a live coralline algal bed and an adjacent sandy habitat: an eddy-covariance study. Mar Ecol Prog Ser 535:99-115. https://doi.org/10.3354/meps11413

Attard KM, Hancke K, Sejr MK, Glud RN (2016) Benthic primary production and mineralization in a High Arctic fjord: in situ assessments by aquatic eddy-covariance. Mar Ecol Prog Ser 554:35-50. https://doi.org/10.3354/meps 11780

Berg P, Huettel M (2008) Monitoring the seafloor using the noninvasive eddy correlation technique: integrated benthic exchange dynamics. Oceanography 21:164-167

Berg P, Røy H, Janssen F, Meyer V, Jorgensen BB, Huettel M, de Beer D (2003) Oxygen uptake by aquatic sediments measured with a novel non-invasive eddy-correlation technique. Mar Ecol Prog Ser 261:75-83. https://doi.org/10.3354/Meps261075

Berg P, Røy H, Wiberg PL (2007) Eddy correlation flux measurements: the sediment surface area that contributes to the flux. 
Limnol Oceanogr 52:1672-1684. https://doi.org/10.4319/ 10.2007.52.4.1672

Berg P et al (2013) Eddy correlation measurements of oxygen fluxes in permeable sediments exposed to varying current flow and light. Limnol Oceanogr 58:1329-1343. https://doi.org/10.4319/ lo.2013.58.4.1329

Boetius A (2013) The expedition of the research vessel "Polarstern" to the Arctic in 2012 (ARK-XXVII/3), vol 663. Alfred Wegener Institute for Polar and Marine Research, Bremerhaven

Boetius A, Wenzhoefer F (2009) Spotlight on technology: in situ technologies for studying deep-sea hotspot ecosystems. Oceanography 22:177

Boetius A et al (2013) Export of algal biomass from the melting Arctic sea ice. Science 339:1430-1432. https://doi.org/10.1126/scien ce. 1231346

Bowman JS (2015) The relationship between sea ice bacterial community structure and biogeochemistry: a synthesis of current knowledge and known unknowns. Elementa 3:72. https://doi. org/10.12952/journal.elementa.000072

Campbell K, Mundy CJ, Gosselin M, Landy JC, Delaforge A, Rysgaard $S$ (2017) Net community production in the bottom of first-year sea ice over the Arctic spring bloom. Geophys Res Lett 44:89718978. https://doi.org/10.1002/2017g1074602

Cox GFN, Weeks WF (1983) Equations for determining the gas and brine volumes in sea-ice samples. J Glaciol 29:306-316

Donis D et al (2015) An assessment of the precision and confidence of aquatic eddy correlation measurements. J Atmos Ocean Technol 32:642-655. https://doi.org/10.1175/Jtech-D-14-00089.1

Eicken H, Kadko D, Perovich DK (2002) Tracer studies of pathways and rates of meltwater transport through Arctic summer sea ice. J Geophys Res 107:2156-2202. https://doi.org/10.1029/2000J $\mathrm{C} 000583$

Else BGT et al (2015) Under-ice eddy-covariance flux measurements of heat, salt, momentum, and dissolved oxygen in an artificial sea ice pool. Cold Reg Sci Technol 119:158-169. https://doi. org/10.1016/j.coldregions.2015.06.018

Fernández-Méndez M, Wenzhofer F, Peeken I, Sørensen HL, Glud RN, Boetius A (2014) Composition, buoyancy regulation and fate of ice algal aggregates in the central Arctic Ocean. PLoS ONE 9:e107452. https://doi.org/10.1371/journal.pone.0107452

Fernández-Méndez M et al (2015) Photosynthetic production in the central Arctic Ocean during the record sea-ice minimum in 2012. Biogeosciences 12:3525-3549. https://doi.org/10.5194/ bg-12-3525-2015

Galley RJ, Else BGT, Geilfus NX, Hare AA, Isleifson D, Barber DG, Rysgaard S (2015) Imaged brine inclusions in young sea iceshape, distribution and formation timing. Cold Reg Sci Technol 111:39-48. https://doi.org/10.1016/j.coldregions.2014.12.011

Glud RN, Rysgaard S, Kuhl M (2002) A laboratory study on $\mathrm{O}_{2}$ dynamics and photosynthesis in ice algal communities: quantification by microsensors, $\mathrm{O}_{2}$ exchange rates, $\mathrm{C}_{14}$ incubations and a PAM fluorometer. Aquat Microb Ecol 27:301-311. https://doi.org/10.3354/ Ame027301

Glud RN, Rysgaard S, Kuhl M, Hansen JW (2007) The sea ice in Young Sound: implications for carbon cycling. In: Rysgaard S, Glud RN (eds) Carbon cycling in Arctic marine ecosystems: case study young sound. Bioscience, vol 58. Meddelelser om Grønland, Copenhagen, pp 62-85

Glud RN, Berg P, Hume A, Batty P, Blicher ME, Lennert K, Rysgaard S (2010) Benthic O2 exchange across hard-bottom substrates quantified by eddy correlation in a sub-Arctic fjord. Mar Ecol Prog Ser 417:1-12. https://doi.org/10.3354/meps08795

Glud RN, Rysgaard S, Turner G, McGinnis DF, Leakey RJG (2014) Biological- and physical-induced oxygen dynamics in melting sea ice of the Fram Strait. Limnol Oceanogr 59:1097-1111. https:// doi.org/10.4319/lo.2014.59.4.1097
Golden KM, Ackley SF, Lytle VI (1998) The percolation phase transition in sea ice. Science 282:2238-2241. https://doi.org/10.1126/ science.282.5397.2238

Grasshoff K, Kremling K, Ehrhardt M (2007) Methods of seawater analysis, 3rd edn. Wiley-VCH, Weinheim. https://doi. org/10.1002/9783527613984

Gundersen JK, Ramsing NB, Glud RN (1998) Predicting the signal of $\mathrm{O}_{2}$ microsensors from physical dimensions, temperature, salinity, and $\mathrm{O}_{2}$ concentration. Limnol Oceanogr 43:1932-1937

Holtappels M, Noss C, Hancke K, Cathalot C, McGinnis DF, Lorke A, Glud RN (2015) Aquatic eddy correlation: quantifying the artificial flux caused by stirring-sensitive $\mathrm{O}_{2}$ sensors. PLoS ONE. https://doi.org/10.1371/journal.pone.0116564

Hudson SR, Granskog MA, Sundfjord A, Randelhoff A, Renner AHH, Divine DV (2013) Energy budget of first-year Arctic sea ice in advanced stages of melt. Geophys Res Lett 40:26792683. https://doi.org/10.1002/grl.50517

Hunke EC, Notz D, Turner AK, Vancoppenolle M (2011) The multiphase physics of sea ice: a review for model developers. Cryosphere 5:989-1009. https://doi.org/10.5194/tc-5-989-2011

Kaartokallio H, Søgaard DH, Norman L, Rysgaard S, Tison JL, Delille B, Thomas DN (2013) Short-term variability in bacterial abundance, cell properties, and incorporation of leucine and thymidine in subarctic sea ice. Aquat Microb Ecol 71:57-73. https://doi.org/10.3354/ame01667

Katlein C, Nicolaus M, Schiller M, Istomina L, Sörensen S, Hendricks S, Krumpen T, Lange B (2012) Sea-ice optics and ROV-operations during ARKXXVII/3- ICEARC 2012. Extended Cruise Report. hdl:10013/epic.40404.d001

Katlein C, Fernández-Méndez M, Wenzhoefer F, Nicolaus M (2014) Distribution of algal aggregates under summer sea ice in the central Arctic. Polar Biol 38:719-731. https://doi.org/10.1007/ s00300-014-1634-3

Katlein C et al (2015) Influence of ice thickness and surface properties on light transmission through Arctic sea ice. J Geophys ResOceans 120:5932-5944. https://doi.org/10.1002/2015jc010914

Kiko R, Kern S, Kramer M, Mütze H (2017) Colonization of newly forming Arctic sea ice by meiofauna: a case study for the future Arctic? Polar Biol 40:1277-1288. https://doi.org/10.1007/s0030 0-016-2052-5

Kohlbach D, Graeve M, Lange BA, David C, Peeken I, Flores H (2016) The importance of ice algae-produced carbon in the central Arctic Ocean ecosystem: food web relationships revealed by lipid and stable isotope analyses. Limnol Oceanogr 61:20272044. https://doi.org/10.1002/lno.10351

Kuhl M, Glud RN, Borum J, Roberts R, Rysgaard S (2001) Photosynthetic performance of surface-associated algae below sea ice as measured with a pulse-amplitude-modulated (PAM) fluorometer and $\mathrm{O}_{2}$ microsensors. Mar Ecol Prog Ser 223:1-14. https://doi. org/10.3354/Meps223001

Lange BA, Katlein C, Nicolaus M, Peeken I, Flores H (2016) Sea ice algae chlorophyll a concentrations derived from under-ice spectral radiation profiling platforms. J Geophys Res Oceans 121:8511-8534. https://doi.org/10.1002/2016jc011991

Leppäranta M, Manninen T (1988) The brine and gas content of sea ice with attention to low salinities and high temperatures Finnish Institute of Marine Research Internal Report, pp 1-14

Long MH, Koopmans D, Berg P, Rysgaard S, Glud RN, Søgaard DH (2012) Oxygen exchange and ice melt measured at the ice-water interface by eddy correlation. Biogeosciences 9:1957-1967. https://doi.org/10.5194/bg-9-1957-2012

Lorke A, McGinnis DF, Maeck A (2013) Eddy-correlation measurements of benthic fluxes under complex flow conditions: effects of coordinate transformations and averaging time scales. Limnol Oceanogr 11:425-437. https://doi.org/10.4319/lom.2013.11.425 
Lorrai C, McGinnis DF, Berg P, Brand A, Wüest A (2010) Application of oxygen eddy correlation in aquatic systems. J Atmos Ocean Technol 27:1533-1546. https://doi.org/10.1175/2010j techo723.1

McGinnis DF, Berg P, Brand A, Lorrai C, Edmonds TJ, Wüest A (2008) Measurements of eddy correlation oxygen fluxes in shallow freshwaters: towards routine applications and analysis. Geophys Res Lett. https://doi.org/10.1029/2007g1032747

McGinnis DF et al (2011) Simple, robust eddy correlation amplifier for aquatic dissolved oxygen and hydrogen sulfide flux measurements. Limnol Oceanogr 9:340-347. https://doi.org/10.4319/ lom.2011.9.340

McGinnis DF, Sommer S, Lorke A, Glud RN, Linke P (2014) Quantifying tidally driven benthic oxygen exchange across permeable sediments: an aquatic eddy correlation study. J Geophys Res 119:6918-6932. https://doi.org/10.1002/2014jc010303

McMinn A, Ashworth C, Ryan KG (2000) In situ net primary productivity of an Antarctic fast ice bottom algal community. Aquat Microb Ecol 21:177-185. https://doi.org/10.3354/ame021177

McPhee MG (2008) Air-ice-ocean interaction: turbulent ocean boundary layer exchange processes. Springer, Berlin

McPhee MG, Maykut GA, Morison JH (1987) Dynamics and thermodynamics of the ice upper ocean system in the marginal ice-zone of the Greenland Sea. J Geophys Res Oceans 92:7017-7031. https ://doi.org/10.1029/JC092iC07p07017

McPhee MG, Kottmeier C, Morison JH (1999) Ocean heat flux in the central Weddell Sea during winter. J Phys Oceanogr 29:1166-1179.

McPhee MG, Stevens CL, Smith IJ, Robinson NJ (2016) Turbulent heat transfer as a control of platelet ice growth in supercooled under-ice ocean boundary layers. Ocean Sci 12:507-515. https:// doi.org/10.5194/os-12-507-2016

Mikkelsen DM, Witkowski A (2010) Melting sea ice for taxonomic analysis: a comparison of four melting procedures. Polar Res 29:451-454. https://doi.org/10.1111/j.1751-8369.2010.00162.x

Miller LA et al (2015) Methods for biogeochemical studies of sea ice: The state of the art, caveats, and recommendations. Elementa. https://doi.org/10.12952/journal.elementa.000038

Nicolaus M, Katlein C (2013) Mapping radiation transfer through sea ice using a remotely operated vehicle (ROV). Cryosphere 7:763777. https://doi.org/10.5194/tc-7-763-2013

NSIDC (2017) Arctic sea ice news and analysis. National Snow and Ice Data Centre. http://nsidc.org/arcticseaicenews/. Accessed 11 Aug 2017

Parkinson CL, DiGirolamo NE (2016) New visualizations highlight new information on the contrasting Arctic and Antarctic sea-ice trends since the late 1970s. Remote Sens Environ 183:198-204. https://doi.org/10.1016/j.rse.2016.05.020

Perovich DK, Tucker WB, Krishfield RA (1989) Oceanic heat-flux in the Fram Strait measured by a drifting buoy. Geophys Res Lett 16:995-998. https://doi.org/10.1029/GL016i009p00995

Peterson AK, Fer I, McPhee MG, Randelhoff A (2017) Turbulent heat and momentum fluxes in the upper ocean under Arctic sea ice. J Geophys Res 122:2169-9291. https://doi.org/10.1002/2016J C012283
Platt T, Gallegos CL, Harrison WG (1980) Photoinhibition of photosynthesis in natural assemblages of marine phytoplankton. J Mar Res 38:687-701

Revsbech NP (1989) An oxygen microsensor with a guard cathode. Limnol Oceanogr 34:474-478

Rheuban JE, Berg P (2013) The effects of spatial and temporal variability at the sediment surface on aquatic eddy correlation flux measurements. Limnol Oceanogr 11:351-359. https://doi.org/10.4319/ lom.2013.11.351

Rivkin RB, Legendre L (2001) Biogenic carbon cycling in the upper ocean: effects of microbial respiration. Science 291:2398-2400. https://doi.org/10.1126/science.291.5512.2398

Rysgaard S, Glud RN (2004) Anaerobic N2 production in Arctic sea ice. Limnol Oceanogr 49:86-94

Rysgaard S, Glud RN (2007) Carbon cycling in Arctic marine ecosystems: case study Young Sound, vol 58. Meddelelser om Grønland, Commission for Scientific Research, Greenland

Rysgaard S, Kuhl M, Glud RN, Hansen JW (2001) Biomass, production and horizontal patchiness of sea ice algae in a high-Arctic fjord (Young Sound, NE Greenland). Mar Ecol Prog Ser 223:15-26. https://doi.org/10.3354/Meps223015

Rysgaard S, Glud RN, Sejr MK, Blicher ME, Stahl HJ (2008) Denitrification activity and oxygen dynamics in Arctic sea ice. Polar Biol 31:527-537. https://doi.org/10.1007/s00300-007-0384-x

Rysgaard $S$ et al (2013) Ikaite crystal distribution in winter sea ice and implications for $\mathrm{CO}_{2}$ system dynamics. Cryosphere 7:707-718. https://doi.org/10.5194/tc-7-707-2013

Sirevaag A (2009) Turbulent exchange coefficients for the ice/ocean interface in case of rapid melting. Geophys Res Lett. https://doi. org/10.1029/2008g1036587

Smith REH, Clement P (1990) Heterotrophic activity and bacterial productivity in assemblages of microbes from sea ice in the high Arctic. Polar Biol 10:351-357. https://doi.org/10.1007/BF00237822

Søgaard DH, Kristensen M, Rysgaard S, Glud RN, Hansen PJ, Hilligsoe KM (2010) Autotrophic and heterotrophic activity in Arctic first-year sea ice: seasonal study from Malene Bight. SW Greenl Mar Ecol Prog Ser 419:31-45. https://doi.org/10.3354/Meps0 8845

Søgaard DH et al (2013) The relative contributions of biological and abiotic processes to carbon dynamics in subarctic sea ice. Polar Biol 36:1761-1777. https://doi.org/10.1007/s00300-013-1396-3

Sørensen HL, Thamdrup B, Jeppesen E, Rysgaard S, Glud RN (2017) Nutrient availability limits biological production in Arctic sea ice melt ponds. Polar Biol 40:1593-1606. https://doi.org/10.1007/ s00300-017-2082-7

Thomas DN (2017) Sea ice, 3rd edn. Wiley, Hoboken

Yen YC, Cheng KC, Fukusako S (1991) Review of intrinsic thermophysical properties of snow, ice, sea ice and frost. In: Zarling JP, Fausett SL (eds) Proceedings of 3rd International Symposium on Cold Regions Heat Transfer, Fairbanks, Alaska, 1991. University of Alaska Fairbanks, pp 187-218

Zhou J, Delille B, Brabant F, Tison JL (2014) Insights into oxygen transport and net community production in sea ice from oxygen, nitrogen and argon concentrations. Biogeosciences 11:5007-5020. https://doi.org/10.5194/bg-11-5007-2014 